\title{
Performance of AGR-1 High-Temperature Reactor Fuel During Post-Irradiation Heating Tests
}

Robert N. Morris ${ }^{\mathrm{a},{ }^{*}}$, Charles A. Baldwin ${ }^{\mathrm{a}}$, Paul A. Demkowicz ${ }^{\mathrm{b}}$, John D. Hunn ${ }^{\mathrm{a}}$, Edward L. Reber ${ }^{\mathrm{b}}$

${ }^{a}$ Oak Ridge National Laboratory

P.O. Box 2008, Oak Ridge TN, 37831-6093, USA

Phone: +011-865-241-4237, morrisrn@ornl.gov

${ }^{b}$ Idaho National Laboratory

P.O. Box 1625, Idaho Falls ID 83415, USA

* Corresponding author 


\section{INTRODUCTION}

The U.S. Department of Energy's Office of Nuclear Energy is supporting the development and qualification of tri-structural isotropic (TRISO) coated particle fuel needed to accelerate the commercialization of hightemperature gas-cooled reactors. TRISO-coated particles consist of four concentric coatings on a spherical kernel of fuel: a low-density carbon buffer, a dense inner pyrolytic carbon (IPyC), a polycrystalline $\mathrm{SiC}$, and a dense outer pyrocarbon (OPyC). These layers are designed to contain fission products throughout the life of the fuel particle. The AGR-1 experiment was the first of a recent series of irradiation tests being performed on cylindrical, graphite-matrix compacts containing TRISO-coated uranium oxide plus uranium carbide (UCO) fuel kernels (Petti et al., 2010). The AGR-1 irradiation test train consisted of six independently monitored capsules, each holding twelve compacts made from one of four TRISO particle composites, one with a baseline TRISO coating design and three with minor coating process variations (Hunn et al., 2007). Post-irradiation, elevatedtemperature performance tests are being conducted at both Idaho National Laboratory (INL) and Oak Ridge National Laboratory (ORNL) to explore the fission product release characteristics of this fuel at temperatures that may be reached during a depressurized conduction cooldown event, which is the accident scenario in which the fuel is exposed to the highest temperatures; the first test was conducted at $1600{ }^{\circ} \mathrm{C}$ in a pure helium atmosphere (Baldwin et al., 2014) and subsequent tests have been conducted at 1600,1700 , and $1800{ }^{\circ} \mathrm{C}$.

The objectives of these furnace tests are as follows: (1) heat the compact in a pure helium atmosphere, and measure the high-temperature time-dependent release of gaseous and condensable fission products from the compact with the Core Conduction Cooldown Test Facility (CCCTF) at ORNL (Baldwin et al., 2014) and with the Fuel Accident Condition Simulator (FACS) furnace system at INL (Demkowicz et al., 2012), (2) measure the inventory of fission products released from the particles but retained in the compact matrix by deconsolidationleach-burn-leach analysis (DLBL) following the furnace test, (3) examine TRISO fuel particles recovered after the deconsolidation to quantify the individual particle retention of specific fission products (including ${ }^{110 \mathrm{~m}} \mathrm{Ag}$, ${ }^{134} \mathrm{Cs},{ }^{137} \mathrm{Cs}$, ${ }^{144} \mathrm{Ce}$, and ${ }^{154} \mathrm{Eu}$ ) with the ORNL Irradiated Microsphere Gamma Analyzer (IMGA), and (4) perform microanalysis on selected particles to better understand the correlation between particle microstructure and fission product retention. Specific details of the CCCTF (Baldwin et al., 2014) and FACS (Demkowicz et al., 2012) design and experimental methods have been previously reported and will not be repeated in this paper.

Briefly, the ORNL CCCTF and INL FACS are high-temperature furnaces designed to test the behavior of coated-particle fuel under simulated accident conditions. The CCCTF furnace (Fig. 1) operates within a dedicated hot cell and can be heated up to a maximum temperature of $2000^{\circ} \mathrm{C}$. The test compact is placed inside a graphite holder within a tantalum can that separates it from the surrounding furnace components. High-purity helium (99.9998\%) is used as a sweep gas to purge the interior of the can through a series of liquid-nitrogencooled charcoal traps outside the CCCTF cell. The traps adsorb any condensable gases and are continuously monitored with $\mathrm{NaI}$ detectors to provide real-time measurement of radioactive fission gas ( $\mathrm{Kr}$ and $\mathrm{Xe}$ ) indicative of diffusive-release or TRISO coating failure. An airlock at the top of the furnace allows for the exchange of a water-cooled cold finger assembly that resides in the upper section of the furnace. The cold finger has a replaceable deposition cup on the end that collects volatile fission products (e.g., Cs, Ag, Pd, I, Sr, and Eu) while it is inside the furnace, thus allowing for periodic measurement of metallic fission product release.

The INL FACS furnace system has a different design (Demkowicz et al., 2012) but performs the same basic functions as the CCCTF. Fission gases released from the fuel to the sweep gas are monitored in real time using dual cryogenic traps fitted with high purity germanium detectors. Condensable fission products are collected on a plate attached to a water-cooled cold finger that can be exchanged periodically and automatically without interrupting the test. A schematic of the furnace system is shown in Fig. 2. While both furnace systems have mostly tantalum parts exposed to the test atmosphere, the CCCTF differs in that it has a graphite fuel holder surrounding the fuel compact that introduces a significant amount of graphite into the test environment. This fuel holder simulates the graphite surrounding the fuel in a prismatic block reactor and can act as a sink for the less volatile fission products such as $\mathrm{Eu}$ and $\mathrm{Sr}$.

The fourteen irradiated AGR-1 compacts used in this furnace test series are described in Table 1. Some of the AGR-1 Baseline fuel properties are shown in Table 2, and additional data on this fuel and the three other AGR-1 fuel types are reported in references (Hunn et al., 2007) and (Phillips et al., 2010). AGR-1 Variant 1 had an increased IPyC deposition temperature resulting in decreased density and anisotropy; while Variant 3 involved an argon diluent in the hydrogen and methyltrichlorosilane used for $\mathrm{SiC}$ deposition to produce a finer grain structure at lower deposition temperature. The TRISO particles were overcoated prior to compacting with a resinated powder containing $64 \mathrm{wt} \%$ natural graphite, $16 \mathrm{wt} \%$ synthetic graphite, and $20 \mathrm{wt} \%$ thermosetting resin (Pappano et al., 2008) that was similar to the German A3-3 matrix recipe (Kania et al., 2015). 


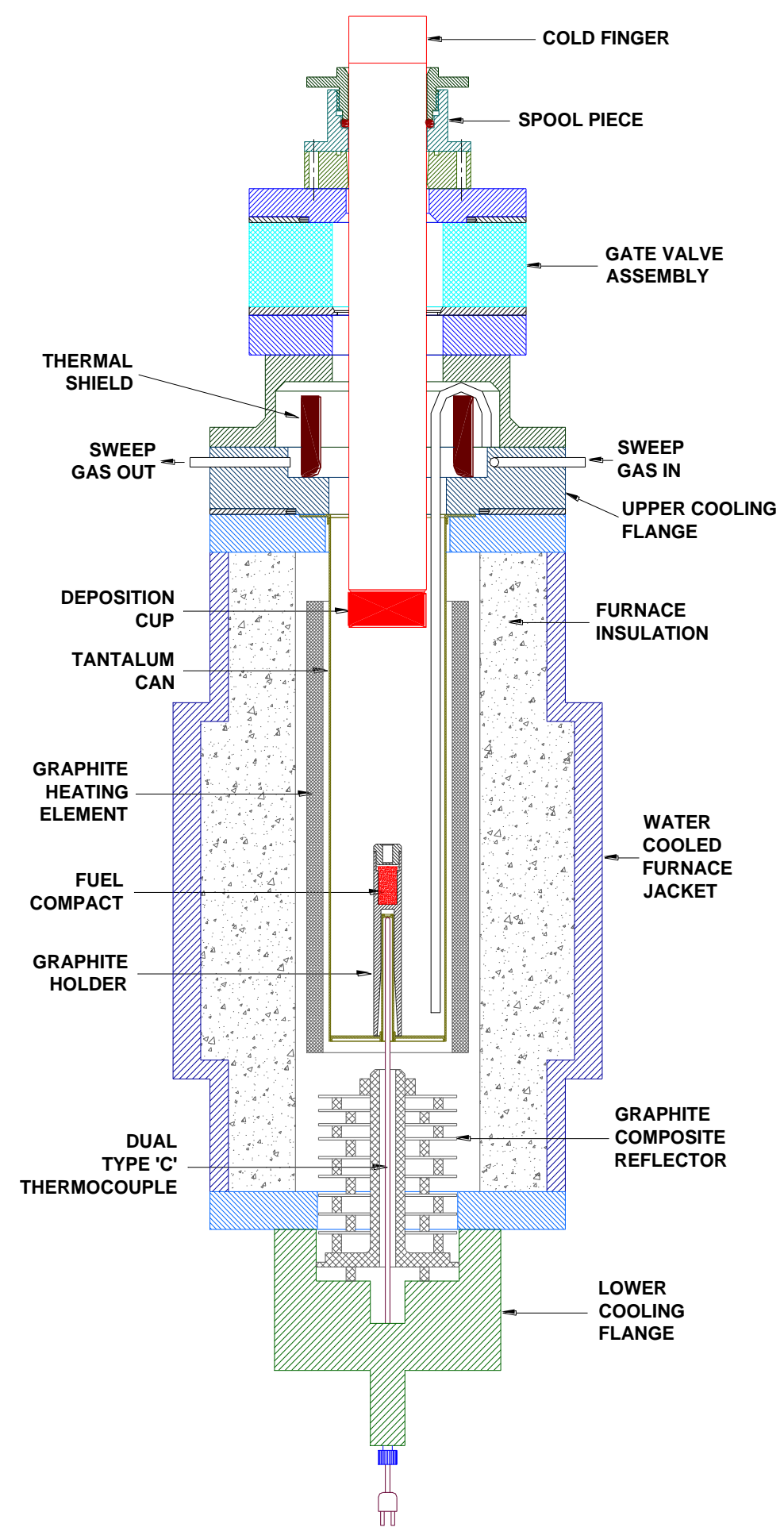

Fig. 1. Schematic of the CCCTF furnace (Baldwin et al., 2014). 


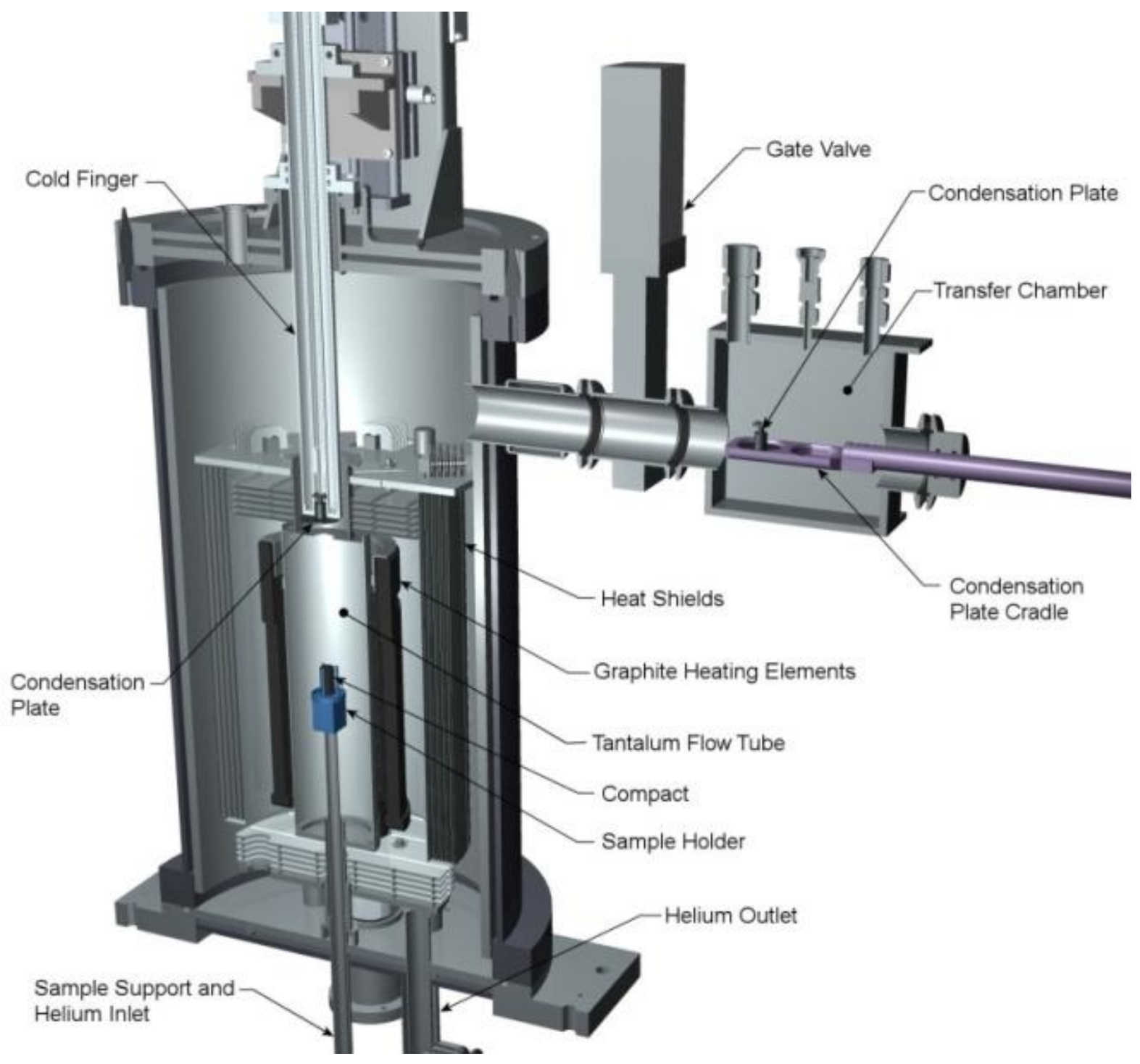

Fig. 2. Schematic of the INL FACS furnace (Demkowicz et al., 2012). 
Table 1. Furnace Test Series Compacts

\begin{tabular}{|c|c|c|c|c|c|c|}
\hline Compact & $\underset{\left(\% \text { FIMA }^{(1)}\right)}{\text { Burnup }}$ & $\begin{array}{c}\text { Fast } \\
\text { Fluence } \\
\left(10^{24} \mathbf{n} / \mathbf{c m}^{2}\right)\end{array}$ & $\begin{array}{c}\text { TAVA }^{(2)} \\
\left({ }^{\circ} \mathbf{C}\right)\end{array}$ & $\begin{array}{c}\text { Test Temp } \\
\left({ }^{\circ} \mathbf{C}\right)\end{array}$ & $\begin{array}{c}\text { Fuel } \\
\text { Type }^{(3)}\end{array}$ & Test Lab \\
\hline $6-2-1$ & 14.2 & 2.87 & 1135 & 1600 & B & ORNL \\
\hline $6-4-1$ & 13.4 & 2.43 & 1041 & 1600 & B & INL \\
\hline $6-4-3$ & 13.4 & 2.46 & 1041 & 1600 & B & ORNL \\
\hline $3-2-2$ & 17.0 & 3.79 & 1019 & 1600 & B & ORNL \\
\hline $3-3-2$ & 17.0 & 3.80 & 1020 & 1600 & B & ORNL \\
\hline $4-1-2$ & 17.4 & 3.72 & 1042 & 1600 & 3 & ORNL \\
\hline $4-3-3$ & 18.6 & 4.16 & 1094 & 1600 & 3 & INL \\
\hline $5-3-3$ & 17.0 & 3.65 & 1042 & 1600 & 1 & ORNL \\
\hline $3-3-1$ & 19.1 & 4.23 & 1051 & 1700 & B & ORNL \\
\hline $4-4-3$ & 19.0 & 4.06 & 1059 & 1700 & 3 & ORNL \\
\hline $3-2-3$ & 19.1 & 4.28 & 1053 & 1800 & B & ORNL \\
\hline $4-3-2$ & 16.4 & 3.68 & 1057 & 1800 & 3 & INL \\
\hline $4-4-1$ & 19.0 & 4.00 & 1057 & 1800 & 3 & ORNL \\
\hline $5-1-3$ & 18.2 & 3.82 & 1042 & 1800 & 1 & ORNL \\
\hline
\end{tabular}

(1) FIMA: fissions per initial metal atom

(2) TAVA: Time-averaged, volume-averaged temperature

${ }^{(3)}$ Fuel Type: Baseline (B) or Variants 1-3

Table 2. Average Baseline AGR-1 Fuel Properties

\begin{tabular}{|c|c|}
\hline Property & Dimension \\
\hline \hline Kernel diameter & $350 \mu \mathrm{m}$ \\
\hline${ }^{235} \mathrm{U}$ enrichment & $19.74 \%$ \\
\hline Buffer thickness & $103.5 \mu \mathrm{m}$ \\
\hline IPyC thickness & $39.4 \mu \mathrm{m}$ \\
\hline SiC thickness & $35.3 \mu \mathrm{m}$ \\
\hline OPyC thickness & $41.0 \mu \mathrm{m}$ \\
\hline Particles/compact & 4145 \\
\hline Packing fraction & $37 \%$ \\
\hline U contamination & $<5 \times 10^{-7}$ \\
\hline
\end{tabular}

\section{FURNACE OPERATION}

Prior to conducting a run, the CCCTF furnace is rebuilt with a new tantalum inner can, gas feedline, and fuel holder so that the system begins at a very low contamination level. Following a safety test, and prior to performing a new test, the FACS furnace is heated to $\mathrm{T} \geq 1600^{\circ} \mathrm{C}$ with no fuel specimen for a duration of at least $24 \mathrm{~h}$, while exchanging several condensation plates. The purpose of this procedure is to reduce the levels of fission products in the furnace hot zone from the preceding test. Analysis of the condensation plates provides verification that residual activity from the previous test does not contribute significantly to the activity detected in the subsequent test.

The general test program proceeds by ramping the furnace to $400{ }^{\circ} \mathrm{C}$ under flowing helium and holding for two hours to bake out water or air that may be present in the fuel compact and furnace components. Next, the furnace is ramped to $1250{ }^{\circ} \mathrm{C}$ and held for $12 \mathrm{~h}$ to complete the baking process and to allow the fuel to come to equilibrium near its irradiation temperature. A deposition cup/plate is usually changed at the end of this period. The furnace is then ramped from $1250{ }^{\circ} \mathrm{C}$ up to the test temperature at a rate of $\sim 50^{\circ} \mathrm{C} / \mathrm{h}$ and a second deposition cup/plate exchange is performed within $1 \mathrm{~h}$ after reaching the test temperature. The next $2-3 \mathrm{cups} / \mathrm{plates}$ are changed at around $12 \mathrm{~h}$ intervals and then the intervals are increased to around $24 \mathrm{~h}$ for the remainder of the test.

Both furnaces have dual thermocouples so that operation can be continued if one should fail; comparison of the two readings provides an indication of any drift. In addition, the furnace power control signal is monitored for changes that would indicate a substantial temperature drift due to a malfunctioning or drifting thermocouple. The thermocouple temperature measurement uncertainty is $\pm 1 \%$ of the reading. 
During the entire test, the fission gas traps are continuously monitored for ${ }^{85} \mathrm{Kr}$, with counting periods of 2$4 \mathrm{~h}$. Unless there is a problem, the trap inventory is allowed to build up during the test; the traps are not emptied until the test is over, at which time the ${ }^{85} \mathrm{Kr}$ in the trap is sometimes removed for optional offline analysis. Dual traps allow the test to continue should one become plugged.

The isotopic inventories deposited on the cups/plates are measured by gamma counting followed by acid leaching for mass spectrometry of stable or long-lived isotopes and to obtain solutions for measuring the beta emitting ${ }^{90} \mathrm{Sr}$ isotope. The fraction of each isotope released from the compact that is collected on the cups/plates, versus being deposited elsewhere in the furnace, is estimated; and the measured isotopic inventory on each cup/plate is divided by this "collection efficiency" to estimate the actual time-dependent release from the compact. The change in compact inventory cannot be directly measured because the release is only a small fraction of the total inventory; therefore, a mass balance between the release measured in the furnace system and the loss from the compact is not possible.

For the CCCTF, the Ta liner and gas inlet tube are gamma counted and leached and the graphite components are ashed and leached; this provides an accounting of the fission products that escaped the compacts but did not reach the deposition cups. Before and after gamma counting of the leached Ta components allows an estimation of Ta component leaching efficiency and controls uncertainty on a case-by-case basis. Generally, gamma counting has a direct uncertainty of $10 \%$, while beta/gamma counting from leaching has a higher uncertainty of $\sim 25 \%$. Strontium presents the greatest difficulty because leaching efficiency cannot be estimated with a reasonable degree of certainty due to the lack of a gamma signature. For the $\mathrm{CCCTF}$ at $1600^{\circ} \mathrm{C}$, the collection efficiencies of the deposition cups are typically: $\mathrm{Ag} \sim 98 \%$, Cs $\sim 84 \%, \mathrm{Eu} \sim 8 \%, \mathrm{Sr} \sim 25 \%$. The efficiencies increase as the test temperature increases and there is considerable run-to-run variation. The CCCTF deposition cup collection efficiencies are separately determined for each test by measuring the isotopic inventories on them and the other furnace components.

For the FACS, internal components are not measured after each test and collection efficiency is based on prior testing. Condensation plate collection efficiencies for the FACS furnace were determined at $1600^{\circ} \mathrm{C}$ by dedicated calibration tests during furnace development using surrogate samples (described in Demkowicz et al., 2012). The efficiencies determined in these tests, and used to determine the compact releases reported here, were: $\operatorname{Ag~} 62 \%( \pm 4.4 \%)$, Cs $66 \%( \pm 21 \%)$, Eu $51 \%( \pm 16 \%)$ and $\mathrm{Sr} 55 \%( \pm 10 \%)$.

\section{REPRESENTATIVE $1600{ }^{\circ} \mathrm{C}$ TESTS}

In the $1600{ }^{\circ} \mathrm{C}$ test range, two tests are of particular interest since they illustrate the release behavior of cesium at this test temperature. The result of the Compact 6-2-1 test is shown in Fig. 3; this compact did not release significant cesium. In contrast, Compact 4-1-2 (Fig. 4) released significant cesium during its test due to a $\mathrm{SiC}$ failure, as was later verified by compact deconsolidation and identification of the failed particle with IMGA (Hunn et al., 2015). Test results are plotted as the cumulative fraction of the total calculated compact inventory (uncertainty estimated to be $7-15 \%$ depending on isotope) generated by the three-year irradiation that was released from the compact during the furnace test. Compact $6-2-1{ }^{134} \mathrm{Cs}$ release (a better indicator of trace levels of cesium release than ${ }^{137} \mathrm{Cs}$ because of lower hot cell contamination due to the much shorter half-life of ${ }^{134} \mathrm{Cs}$ limiting its accumulation) was below $5 \times 10^{-6}$; while in the test of Compact 4-1-2, the collected cesium was an appreciable fraction of one particle (one particle is equivalent to a compact fraction of $2.4 \times 10^{-4}$ ). Neither compact released significant radioactive gas during its furnace test $\left({ }^{85} \mathrm{Kr}\right.$ was near or below detection levels). This indicates that at least one pyrocarbon layer remained intact to retain gaseous fission products in the Compact 4-1-2 particle with failed $\mathrm{SiC}$ and no other particles in either compact had failed TRISO. Fig. 3 also illustrates that the other measured isotopes do not generally track the Cs behavior, with many particle's worth of $\mathrm{Ag}, \mathrm{Eu}$, and $\mathrm{Sr}$ released from Compact 6-2-1 even though the Cs release was negligible. This suggests a source of release for these elements independent of $\mathrm{SiC}$ containment failure, as discussed in the next section. 


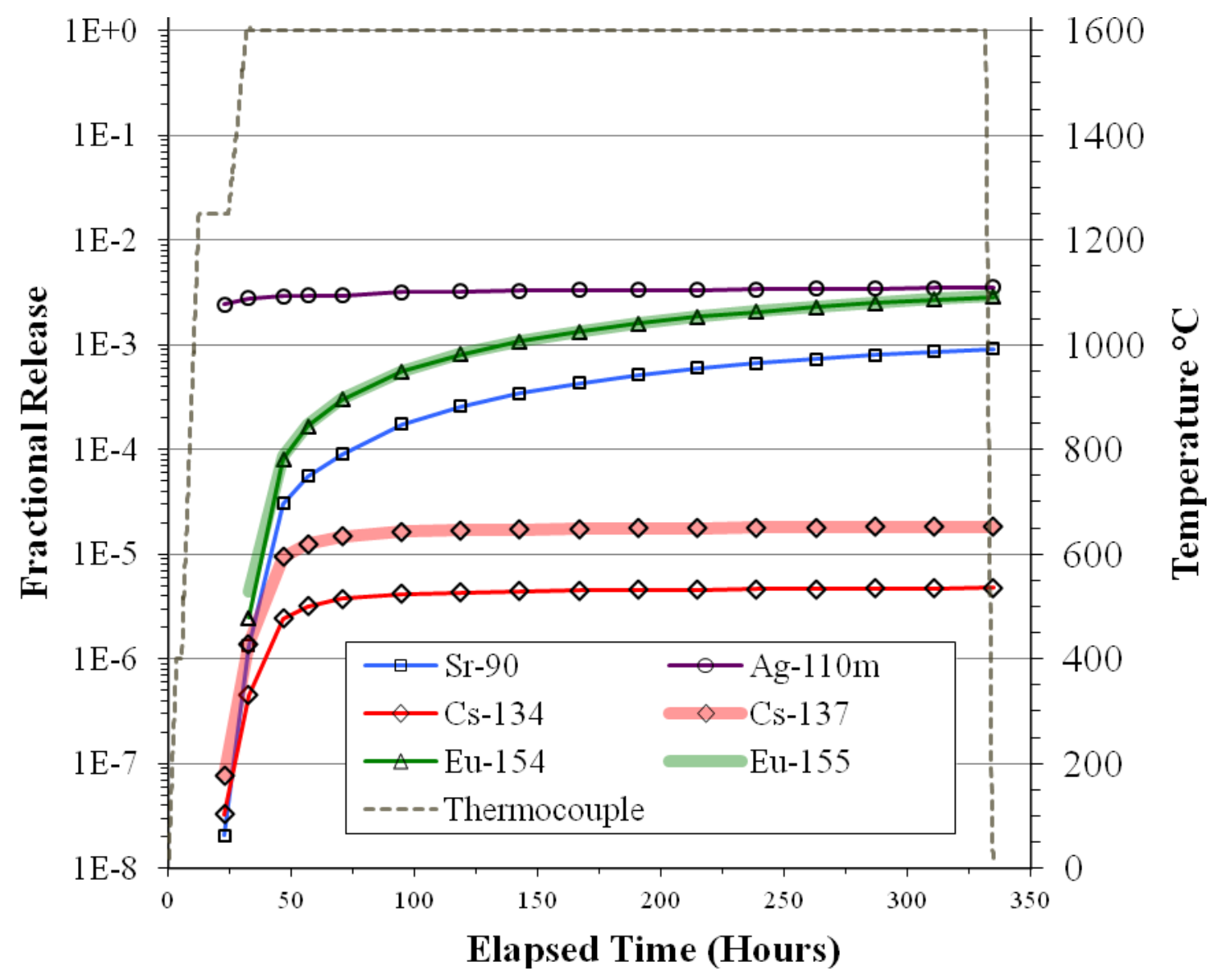

Fig. 3. Compact 6-2-1 test results. Cesium release was very low; higher ${ }^{137} \mathrm{Cs}$ accumulation, compared to ${ }^{134} \mathrm{Cs}$, indicates hot cell contamination. 


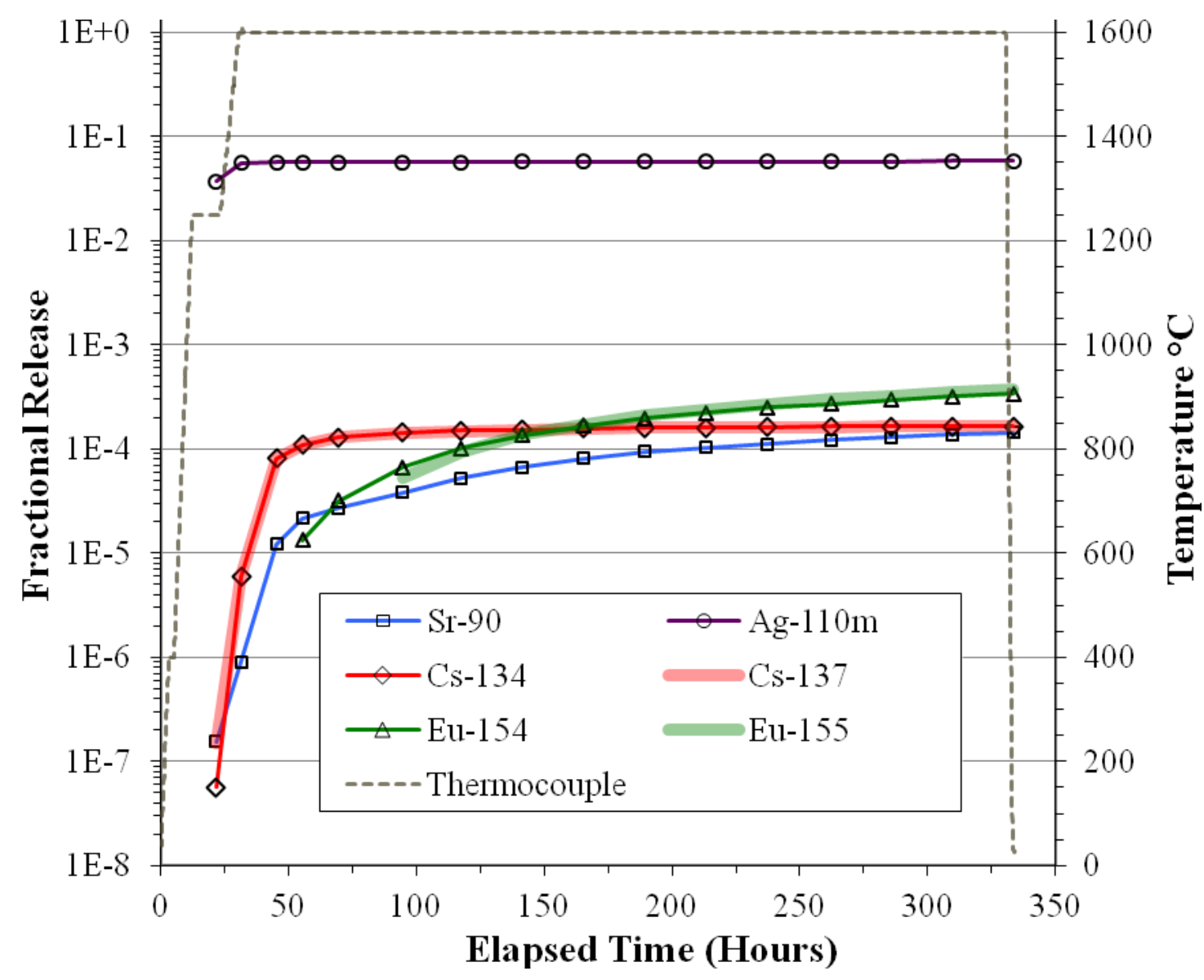

Fig. 4. Compact 4-1-2 test results. Cesium release above $10^{-4}$ indicates that this compact contained a particle whose $\mathrm{SiC}$ layer was not intact.

\section{AGGREGATE $1600{ }^{\circ} \mathrm{C}$ TESTS}

A total of eight runs at $1600{ }^{\circ} \mathrm{C}$ have been conducted to date. A major observation is that the fission products were released as the compacts came up to temperature and unless a $\mathrm{SiC}$ failure occurred, the $\mathrm{Ag}$ and $\mathrm{Cs}$ releases quickly tapered off with time while the $\mathrm{Sr}$ and Eu releases tended toward a relatively constant rate. Composite results for krypton release are not reported here because they were near or below ${ }^{85} \mathrm{Kr}$ detection levels for the entire $1600{ }^{\circ} \mathrm{C}$ test series, corresponding to a release fraction of $<5 \times 10^{-6}$ for all tests.

The overall cesium release results for the $1600{ }^{\circ} \mathrm{C}$ test series are shown in Fig. 5, where ${ }^{134} \mathrm{Cs}$ is presented because it is less influenced by hot cell contamination than ${ }^{137} \mathrm{Cs}$, as previously discussed. Cumulative ${ }^{134} \mathrm{Cs}$ fractional release for five out of the eight compacts tested at $1600{ }^{\circ} \mathrm{C}$ was below $10^{-5}$ (corresponding to a few percent of a single particle's inventory). Significant cesium release was connected with failed SiC; the three compacts that released cesium each had one particle with failed $\mathrm{SiC}$. The cesium releases from Compacts 4-1-2 and 3-3-2 were investigated in detail to locate the cesium-releasing particles (Hunn et al., 2015). 


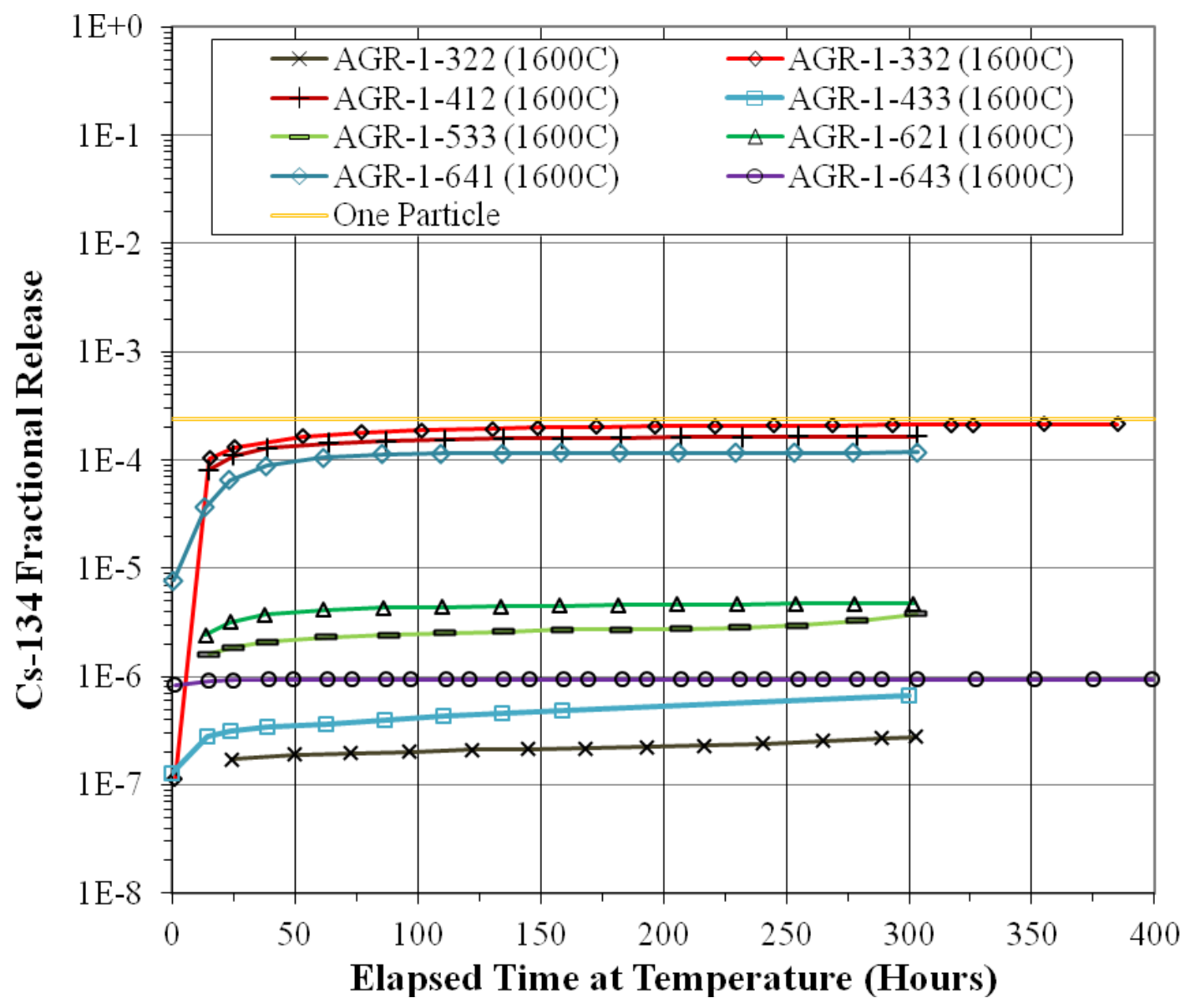

Fig. 5. Cesium release results for the $1600{ }^{\circ} \mathrm{C}$ test series. Note the large difference between the three compacts that released cesium due to failed $\mathrm{SiC}$.

Silver release was much higher than cesium, with compacts releasing the equivalent of 10-1000 particle's ${ }^{110 \mathrm{~m}} \mathrm{Ag}$ inventory (Fig. 6). Silver release did not correspond to the presence of particles with failed SiC; for example, one of the lowest Cs releasing compacts, Compact 4-3-3, had the highest ${ }^{110 \mathrm{~m}} \mathrm{Ag}$ release. It should also be noted that although the release fractions are based on the calculated inventory, many compacts started the test with a reduced inventory, due to silver release during irradiation (Demkowicz et al., 2015-1). 


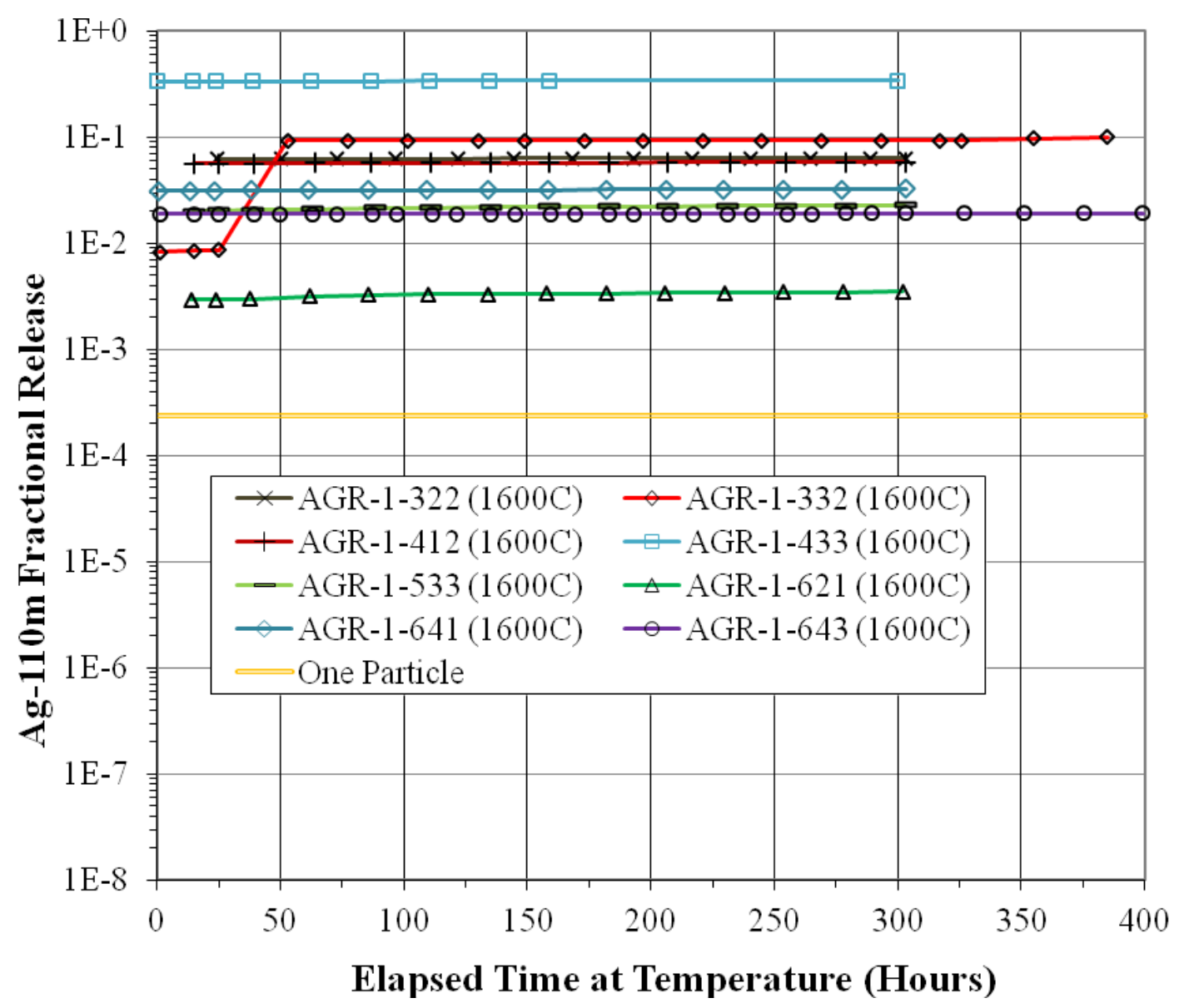

Fig. 6. Silver release results for the $1600{ }^{\circ} \mathrm{C}$ test series. Note the large range in measured release. The abnormal Compact 3-3-2 two-step release will be explained in the next section.

Silver and cesium demonstrated a relatively rapid release behavior. When releases occurred, either as compacts were heated to $1600{ }^{\circ} \mathrm{C}$ or when $\mathrm{SiC}$ failures occurred early in the testing, cumulative values quickly approached their maximum and then plateaued. This is indicative of fast release from the carbonaceous material outside of intact $\mathrm{SiC}$ rather than slower diffusion through intact $\mathrm{SiC}$. It cannot be determined if the comparatively small gradual accumulation later in the test was due to release through intact SiC or simply from residual inventory in the matrix and OPyC. The less volatile elements, europium and strontium, displayed a release behavior with a much longer rise time as compared to silver and cesium (Fig. 7 and Fig. 8).

In six of the eight $1600{ }^{\circ} \mathrm{C}$ tests, Eu releases were equivalent to 3-12 particle's inventory, even though two of those compacts (Compacts 3-3-2 and 6-4-1) only had single-particle SiC failures and the other four compacts had none. In the remaining two tests, where each compact released closer to one particle's Eu inventory, only Compact 4-1-2 had a SiC failure. The greatest Eu release was from Compact 6-2-1, which did not contain any particles with failed SiC. Thus, Eu release was not strongly connected with $\mathrm{SiC}$ failure.

Sr release approximately paralleled Eu release, but at a lower level (compacts that released more Eu also tended to release about the same fraction more Sr). Six compacts had releases either slightly below or significantly above one particle's worth of Sr, but only three of those (3-3-2, 4-1-2, and 6-4-1) were found to have single $\mathrm{SiC}$ failures. As for $\mathrm{Eu}$, the greatest release was from Compact 6-2-1; thus, Sr release also was not obviously coupled to $\mathrm{SiC}$ failure. Recovering and measuring ${ }^{90} \mathrm{Sr}$ from furnace components was difficult so part of the wider range of releases in Fig. 8 may be due to incomplete ${ }^{90} \mathrm{Sr}$ recovery or uncertainties in the estimated deposition cup collection efficiency.

Post-test DLBL showed that europium and strontium were distributed throughout the OPyC, matrix, graphite holder, and tantalum furnace components; this observation, in conjunction with the gradual accumulation on the water-cooled collectors, suggests slow release of europium and strontium from the carbonaceous material.

As discussed above, while any significant $\mathrm{Cs}$ release typically corresponded to the number of particles with failed $\mathrm{SiC}$, other isotopic releases ( $\mathrm{Ag}, \mathrm{Eu}$, and $\mathrm{Sr}$ ) did not appear to be related to the same mechanism. In addition, the combined cumulative heating test releases and residual inventories detected by DLBL were comparable to measured inventories in the matrix and OPyC of as-irradiated compacts (Demkowicz et al., 
2015-1). This leads to a hypothesis that, in the absence of $\mathrm{SiC}$ failures, the dominate source of fission products in these tests is from the inventory that has accumulated in the matrix and OPyC from diffusive release through intact $\mathrm{SiC}$ during irradiation. The hypothesis is strongest for $\mathrm{Ag}$ and $\mathrm{Cs}$ because of their rapid movement at temperature and very low residual post-heating inventories, but weaker for $\mathrm{Sr}$ and Eu because they are less volatile at temperature and had higher post-heating inventories, making it difficult to separate a modest SiC release during heating from the gradual release of a relatively large starting inventory in the matrix and OPyC.

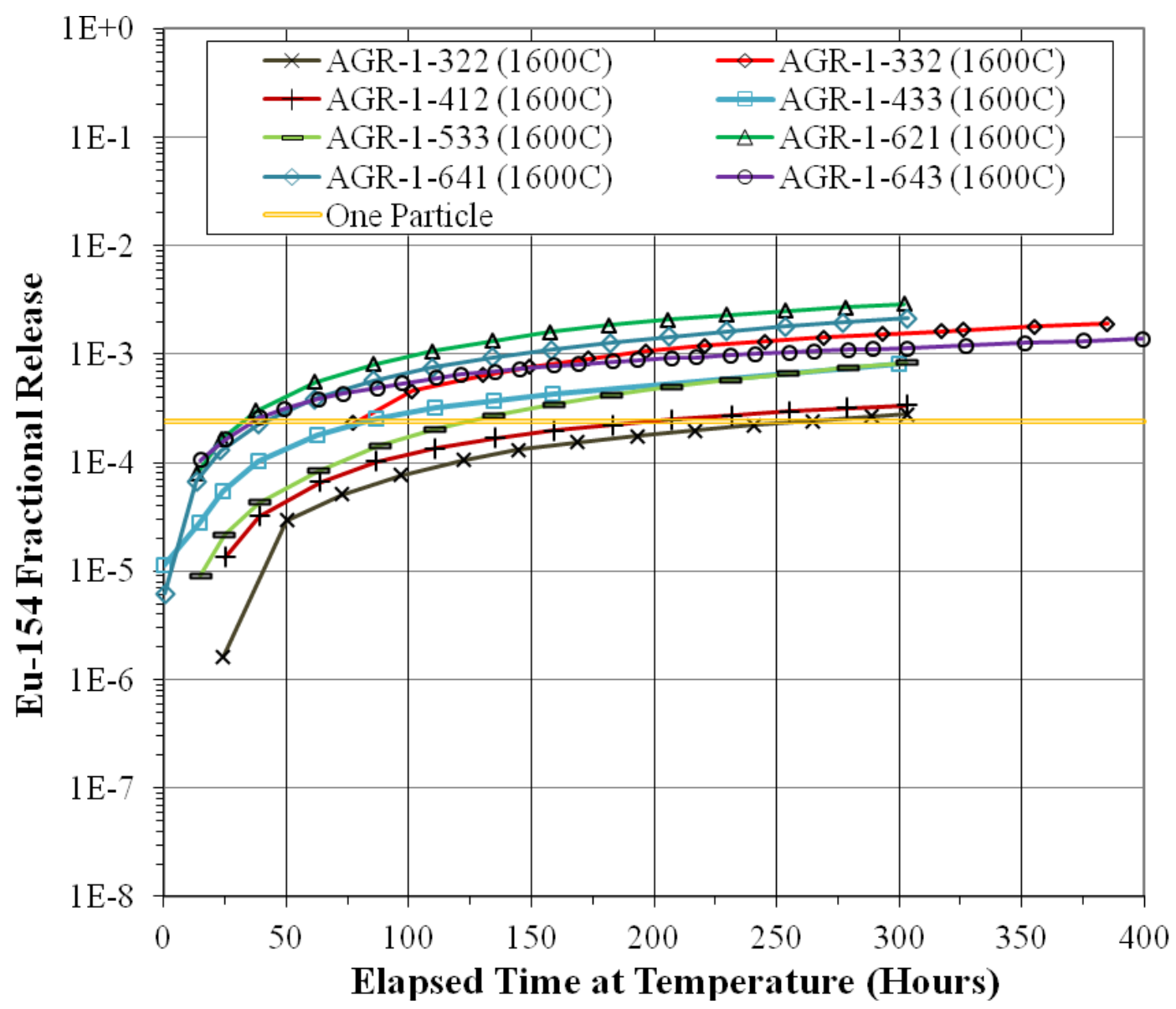

Fig. 7. Europium release results for the $1600^{\circ} \mathrm{C}$ test series. Note the relatively narrow range of values across all tests. 


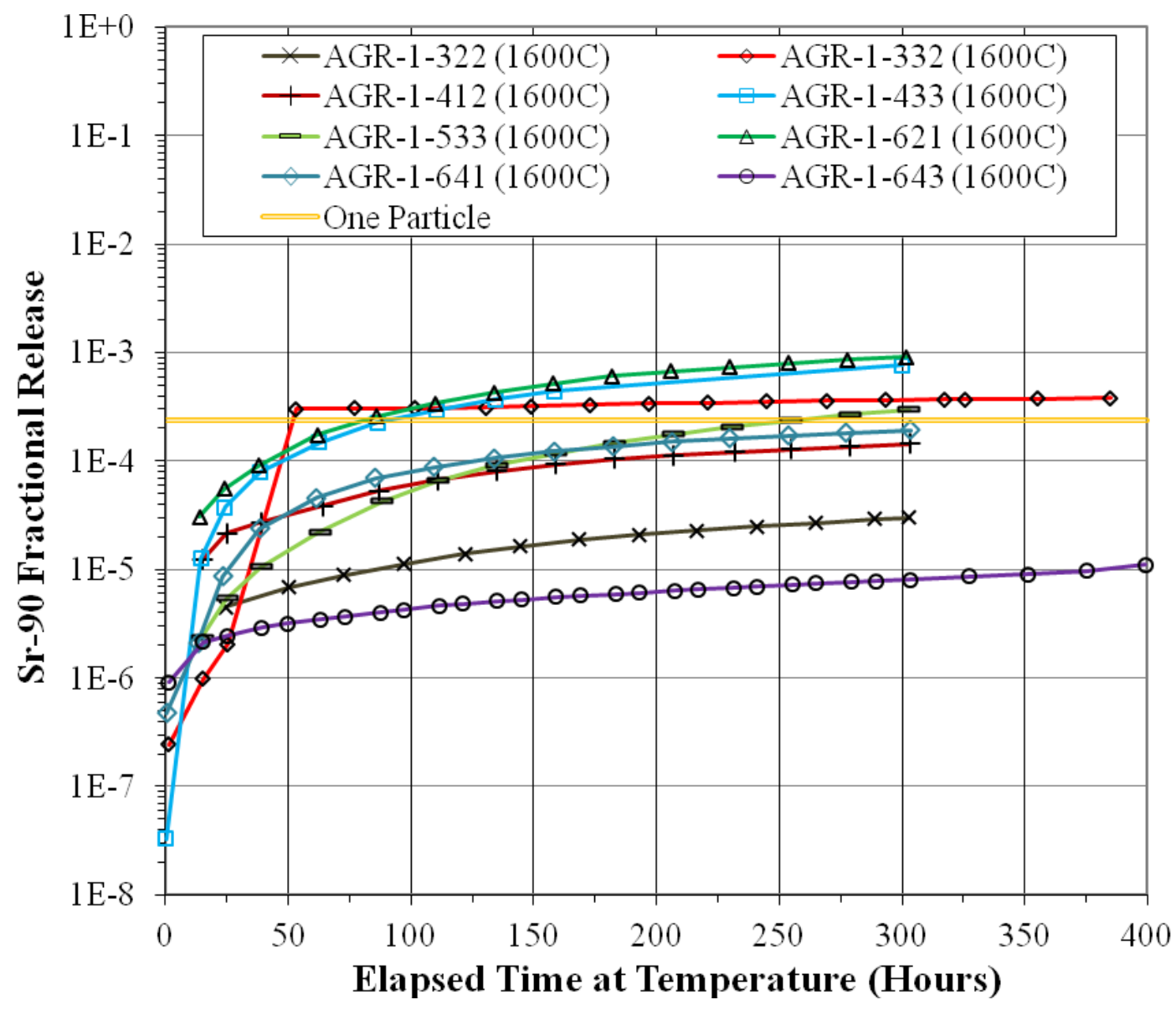

Fig. 8. Strontium release results for the $1600^{\circ} \mathrm{C}$ test series.

\section{TEMPERATURE CYCLING AND SILVER RELEASE}

Some furnace problems were encountered during early testing in the CCCTF and these problems led to the discovery of some unusual silver release behavior. Fig. 9 shows one example, where it was noted during Compact 3-3-2 testing that temperature cycling at the beginning of the test led to the additional release of silver even after the initial release had plateaued. The effect was only seen with Ag and does not appear to be connected to the single-particle with failed $\mathrm{SiC}$ that released cesium around 100 hours into the test.

Temperature cycling during the Compact 3-3-2 test was due to furnace power supply problems at the beginning of the test and intentional thermal cycling at the end of the test to further study the effect and see if thermal cycling still resulted in silver release after the long $1600{ }^{\circ} \mathrm{C}$ soak. Even though negligible ${ }^{110 \mathrm{~m}} \mathrm{Ag}$ had been released over a period of $250 \mathrm{~h}$, additional silver release from thermal cycling was still observable, albeit at a much lower lever (Fig. 10 shows the ${ }^{110 \mathrm{~m}} \mathrm{Ag}$ on a linear scale). Further studies are being conducted to explore this effect. Two possibilities under consideration are that silver could be coming through intact $\mathrm{SiC}$ in a temperature range less than $1600{ }^{\circ} \mathrm{C}$ and that temperature changes or some other dynamic process that may exist during thermal ramping could be enhancing silver release through intact $\mathrm{SiC}$. 


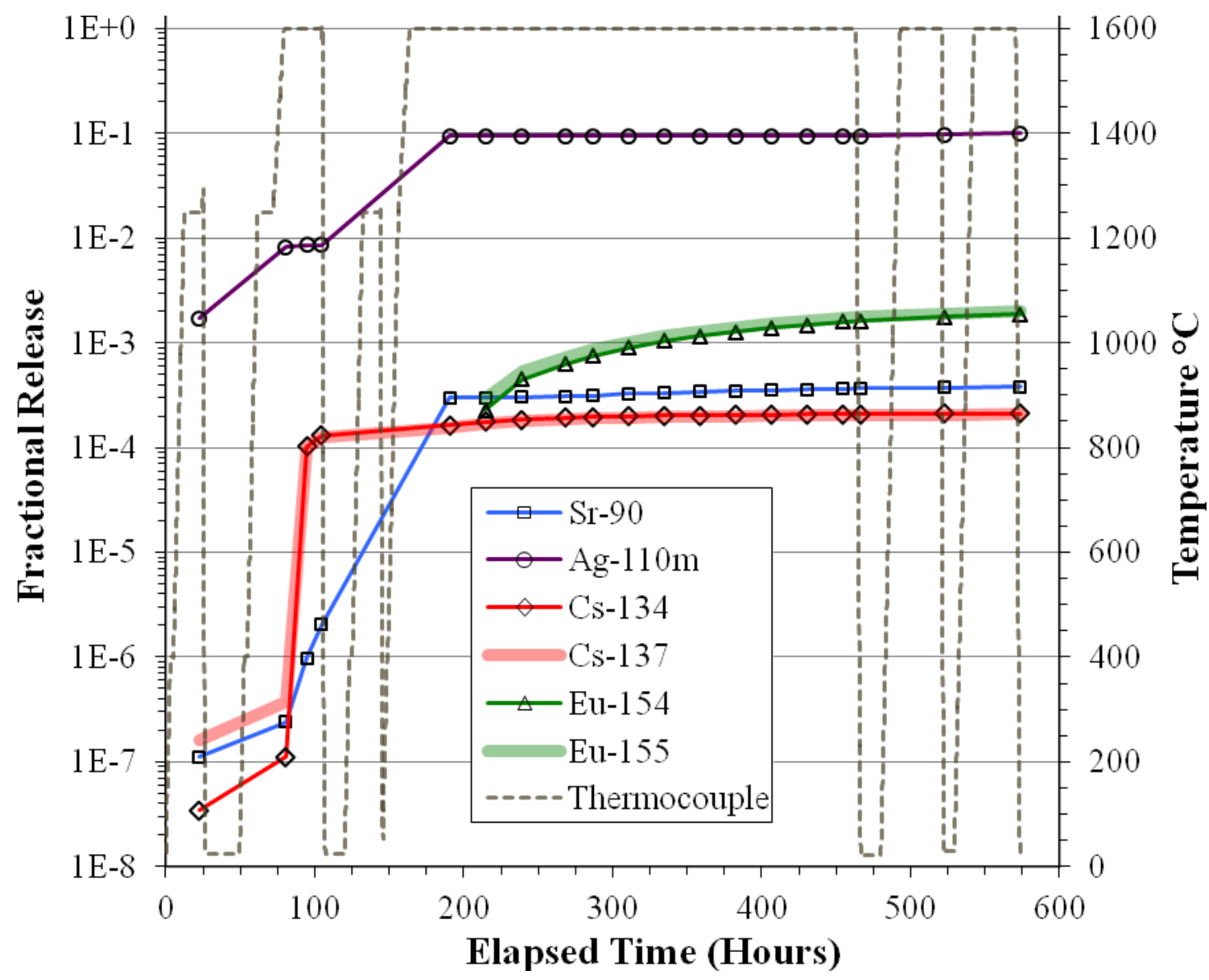

Fig. 9. Temperature cycling and enhanced silver release from Compact 3-3-2. Note the increase in ${ }^{110 \mathrm{~m}} \mathrm{Ag}$ at $200 \mathrm{~h}$, even though it had plateaued during the initial soak at $1600{ }^{\circ} \mathrm{C}$; the release was many times more than would come from the particle that released Cs during the initial $1600{ }^{\circ} \mathrm{C}$ soak. 


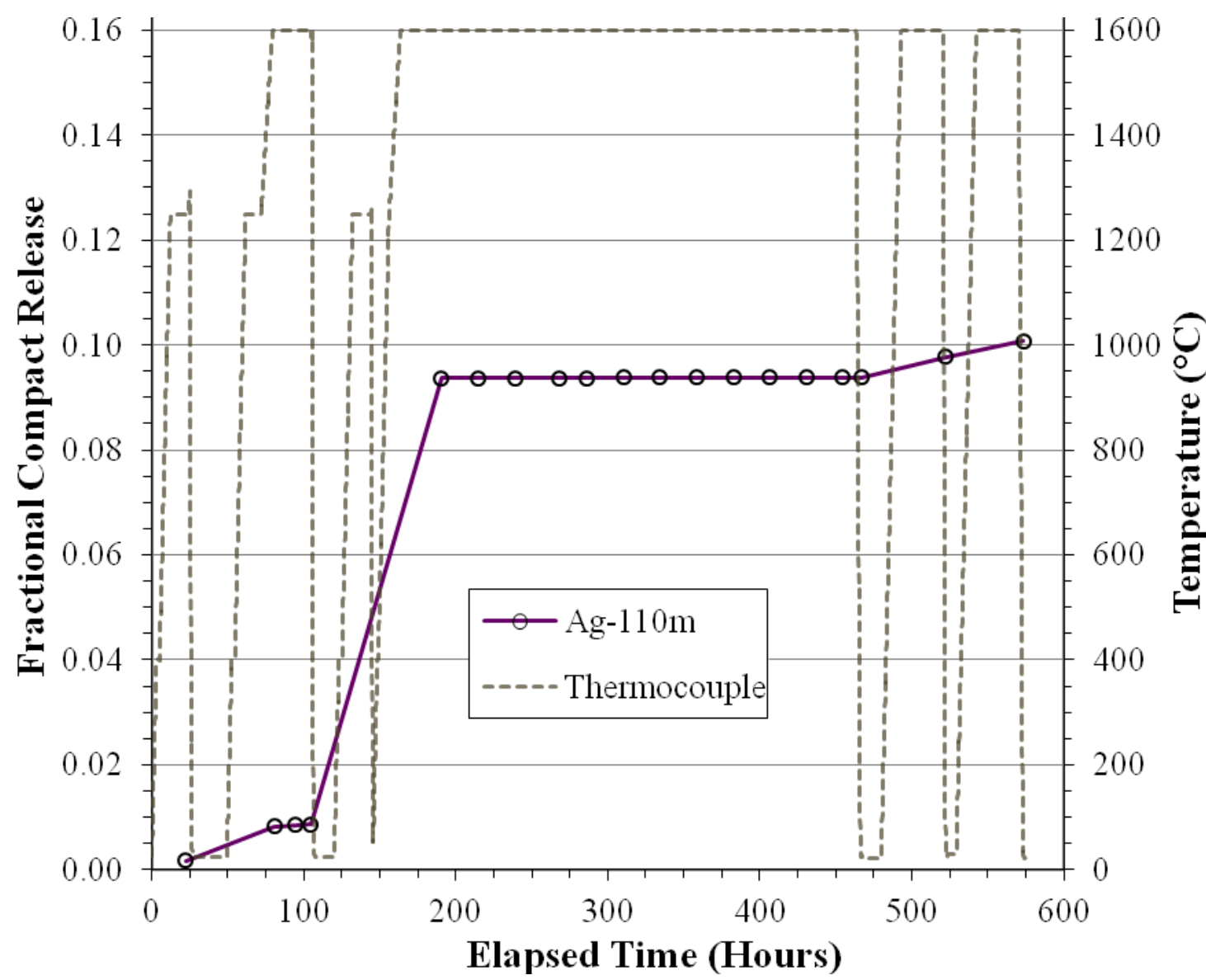

Fig. 10. Silver data from plotted on a linear scale, showing enhanced silver release from Compact 3-3-2 due to temperature cycling.

\section{SCOPING TESTS AT $1700{ }^{\circ} \mathrm{C}$}

Two margin tests were conducted at $1700{ }^{\circ} \mathrm{C}$ to determine if there was a significant change in release behavior compared to $1600{ }^{\circ} \mathrm{C}$ and overall behavior was found to be similar. Cesium release results are shown in Fig. 11. In the absence of failed $\mathrm{SiC}$, cesium release from Compact 4-4-3 was very low, similar to the $1600{ }^{\circ} \mathrm{C}$ tests. This shows that intact $\mathrm{SiC}$ continues to retain cesium well at this temperature (the slight increase in cesium release at the end of the Compact 4-4-3 test was still low compared to possible hot cell contamination).

Cesium release from Compact 3-3-1 equivalent to the inventory in $\sim 1.5$ particles indicated multiple particles released cesium. IMGA survey detected two particles with failed SiC, and DLBL suggested the existence of two more that did not remain intact through the deconsolidation and leaching process to be available for survey (Hunn et al., 2015). So whereas the average cesium retention at $1700{ }^{\circ} \mathrm{C}$ appeared to be as good as it was at $1600{ }^{\circ} \mathrm{C}$, the likelihood for individual particle failure appeared to be slightly higher. Fractional release of ${ }^{85} \mathrm{Kr}$ was again very low for this series $\left(<5 \times 10^{-6}\right)$ indicating that the particles with failed $\mathrm{SiC}$ retained at least one intact pyrocarbon layer throughout the furnace test. Silver, europium, and strontium also exhibited release behavior similar to that seen at $1600{ }^{\circ} \mathrm{C}$ (Fig. 12). Compact aggregate releases exceeded any extra release from the four particles with $\mathrm{SiC}$ failures in Compact 3-3-1 (a fractional release of $10^{-3}$ is about equivalent to the inventory in four particles). Like Compact 3-3-2, the heating test for Compact 3-3-1 was somewhat unusual in that there were two power interruptions during the $1250{ }^{\circ} \mathrm{C}$ soak period which resulted in additional thermal cycling. Additional silver release from thermal cycling was again observed, with each thermal cycle resulting in a modest, but measurable ${ }^{110 \mathrm{~m}} \mathrm{Ag}$ release (Fig. 13). 


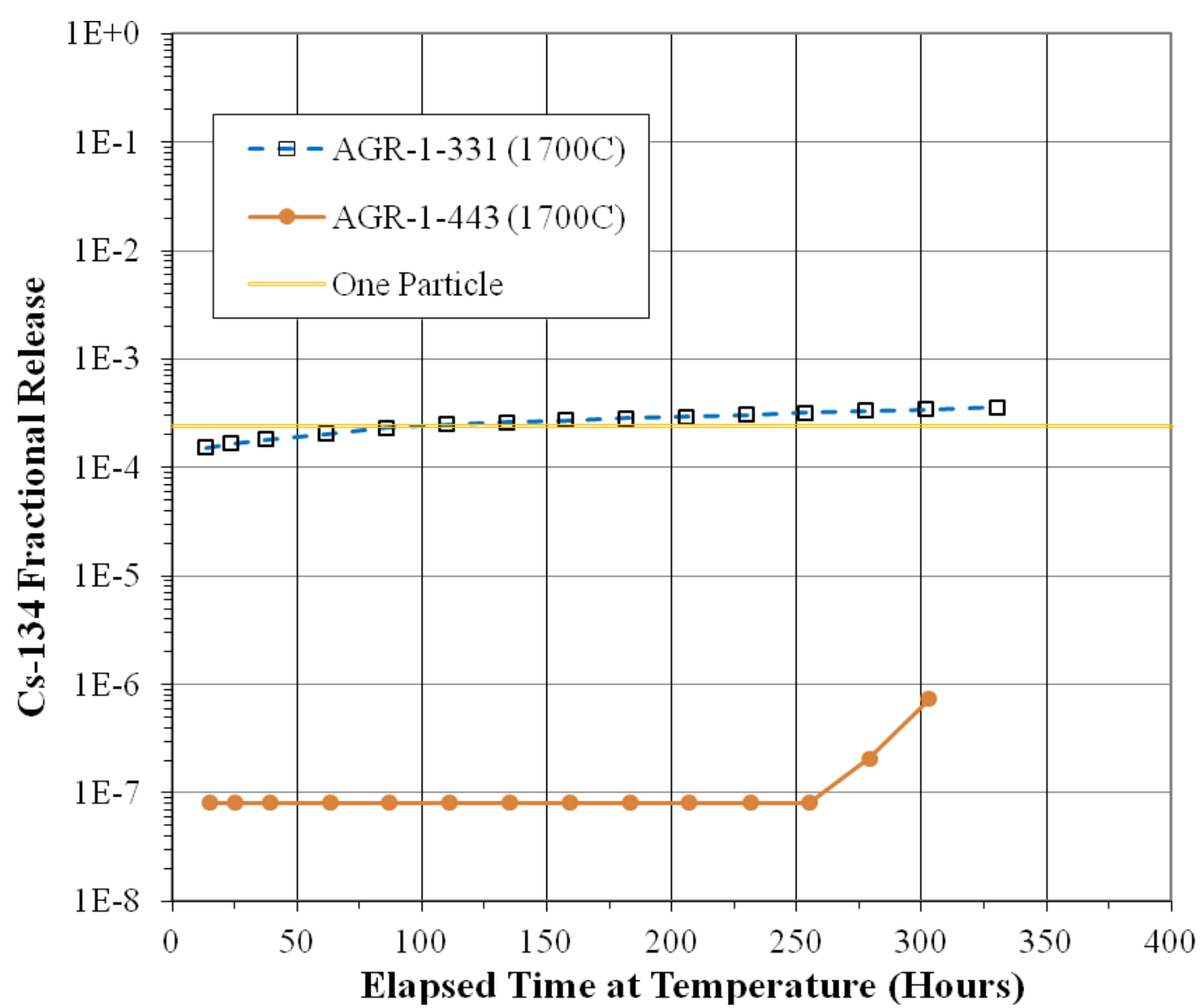

Fig. 11. Cesium release results for the $1700{ }^{\circ} \mathrm{C}$ test series. Compact 3-3-1 had an estimated four particles with failed $\mathrm{SiC}$. 


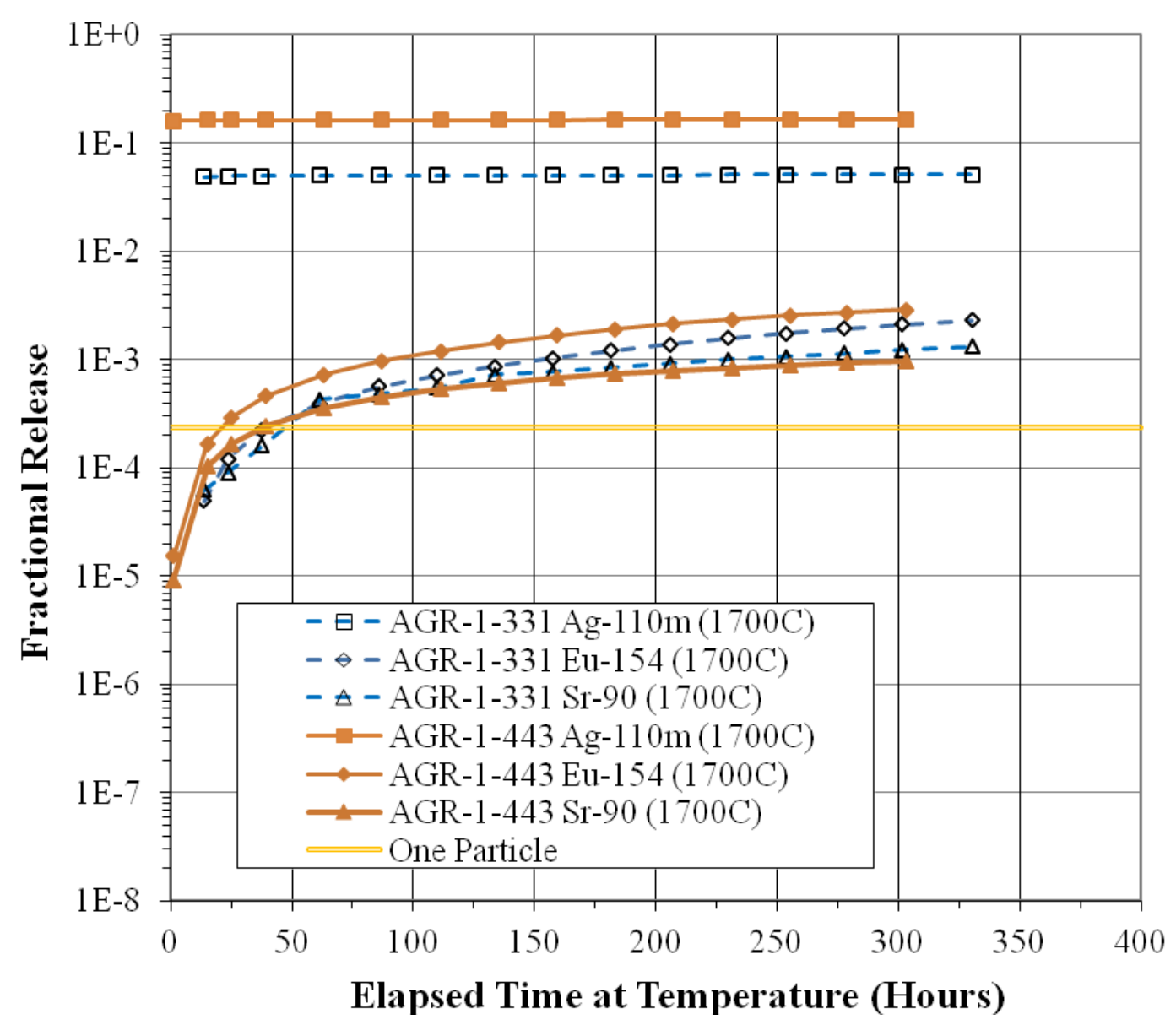

Fig. 12. Silver, europium, and strontium release results for the $1700^{\circ} \mathrm{C}$ test series. 


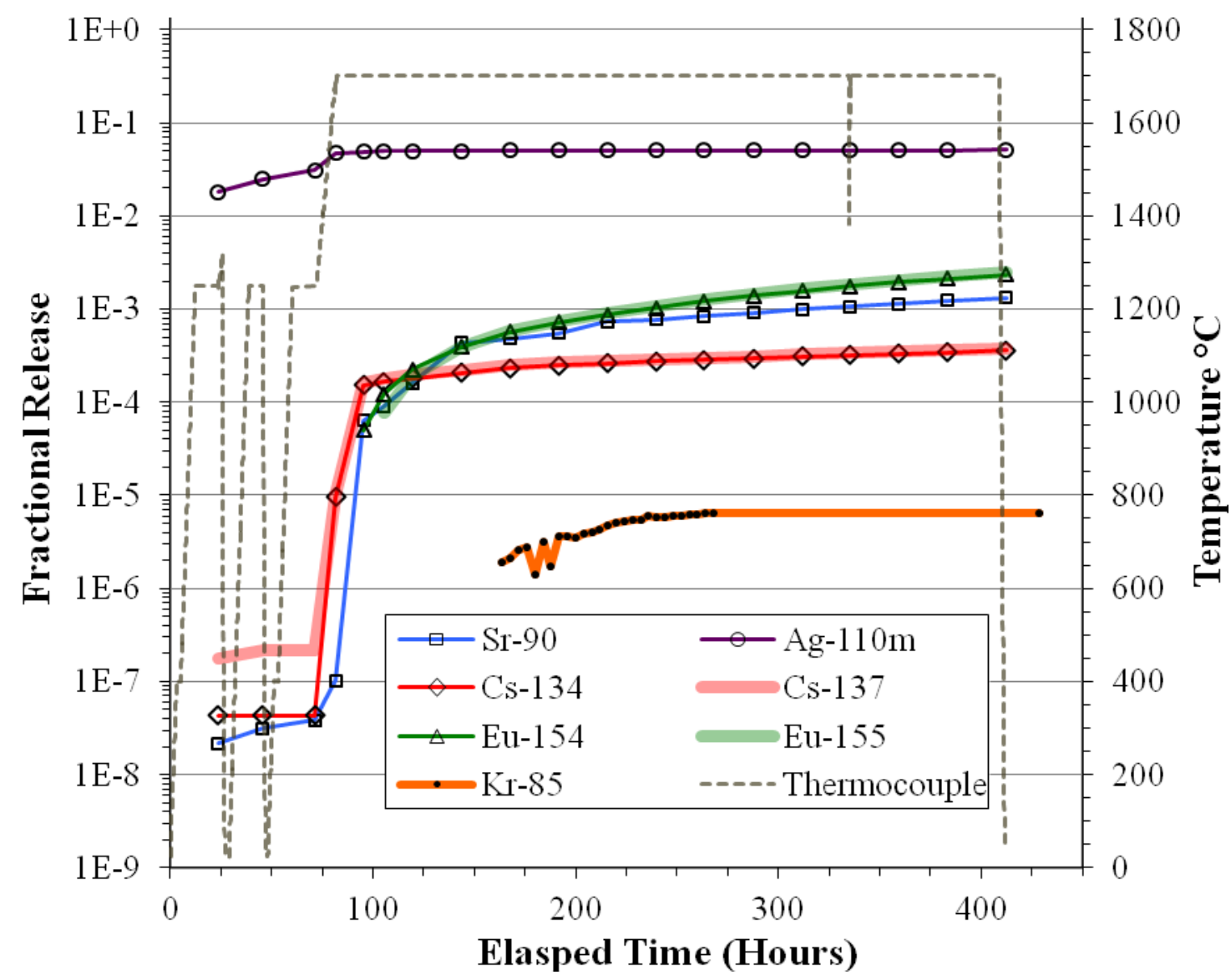

Fig. 13. Release results for Compact 3-3-1 at $1700{ }^{\circ} \mathrm{C}$. Note the temperature cycling during the $1250{ }^{\circ} \mathrm{C}$ phase and the increasing silver release.

\section{7. $1800^{\circ} \mathrm{C}$ TESTS}

A test series was run at $1800{ }^{\circ} \mathrm{C}$ to increase the likelihood for detecting diffusive release and to further explore the SiC performance margin at this very high temperature. All four tests resulted in several particles with failed SiC. In addition, the release behavior for silver, europium, and strontium was different in the latter part of the tests from what was observed at the lower test temperatures. All of the $1800{ }^{\circ} \mathrm{C}$-tested compacts released significant amounts of cesium due to multiple particles with failed $\mathrm{SiC}$; and, in this limited sampling, the Variant 3 compacts (4-3-2 and 4-4-1), which had a finer-grained SiC microstructure (Phillips et al., 2010), released cesium later in the heating cycle (Fig. 14).

Fig. 15 shows significant ${ }^{85} \mathrm{Kr}$ release from what appears to be two Compact 4-3-2 particles with none of the three outer TRISO layers intact, and much lower, but detectable ${ }^{85} \mathrm{Kr}$, from what might be diffusive release through particles with failed $\mathrm{SiC}$ and intact pyrocarbon. Note that the krypton release in the latter part of the Compacts 4-3-2 test was extremely rapid, and totaled approximately $100 \%$ of the predicted single-particle inventory in both cases. Additional details of the krypton and cesium release from this compact are discussed in another paper (Demkowicz et al., 2015-2).

Fig. 16 and Fig. 17 show the ${ }^{154} \mathrm{Eu}$ and ${ }^{90} \mathrm{Sr}$ releases from the four compacts tested at $1800{ }^{\circ} \mathrm{C}$; two patterns are evident. As observed in the lower temperature furnace tests, europium and strontium releases from a given compact tended to track together. Total releases for these four compacts were similar and greater than the $1600{ }^{\circ} \mathrm{C}$ total releases, but the release curves start at a high rate and decrease for Baseline and Variant 1 fuel (Compacts 3-2-3 and 5-1-3, respectively) and do the opposite for the two Variant 3 compacts (implying SiC diffusion in these compacts). Although this behavior has not yet been directly connected to the $\mathrm{SiC}$ microstructure, it is interesting given that the Baseline and Variant $1 \mathrm{SiC}$ layers were deposited using the same deposition conditions (methyl-trichlorosilane with hydrogen) and the Variant $3 \mathrm{SiC}$ layers were deposited with the addition of argon gas to produce a finer grain structure (Phillips et al., 2010). 


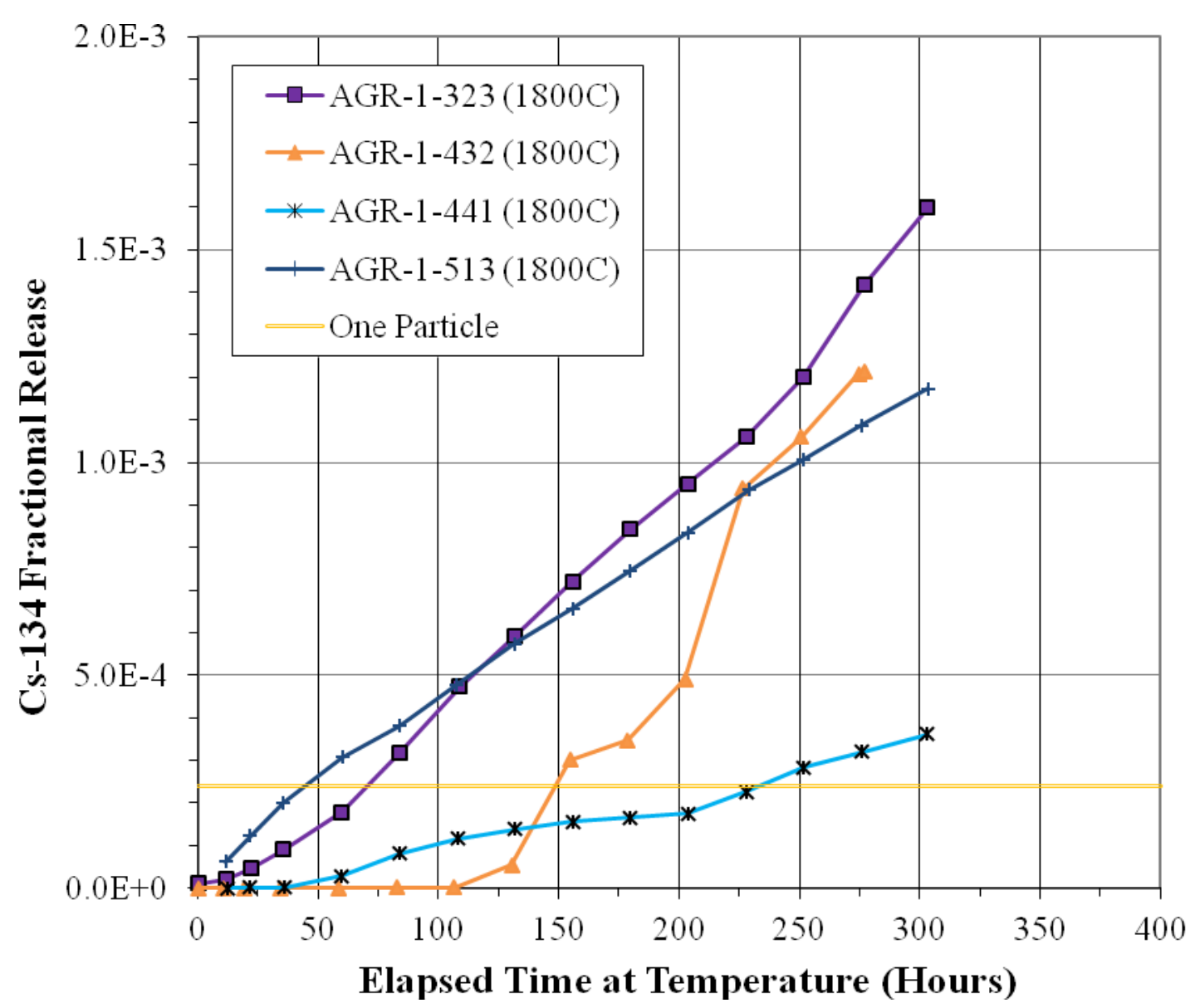

Fig. 14. Cesium release for $1800{ }^{\circ} \mathrm{C}$ tests. Note the linear scale for this and the following graphs. Variant 3 compacts showed a later release. 


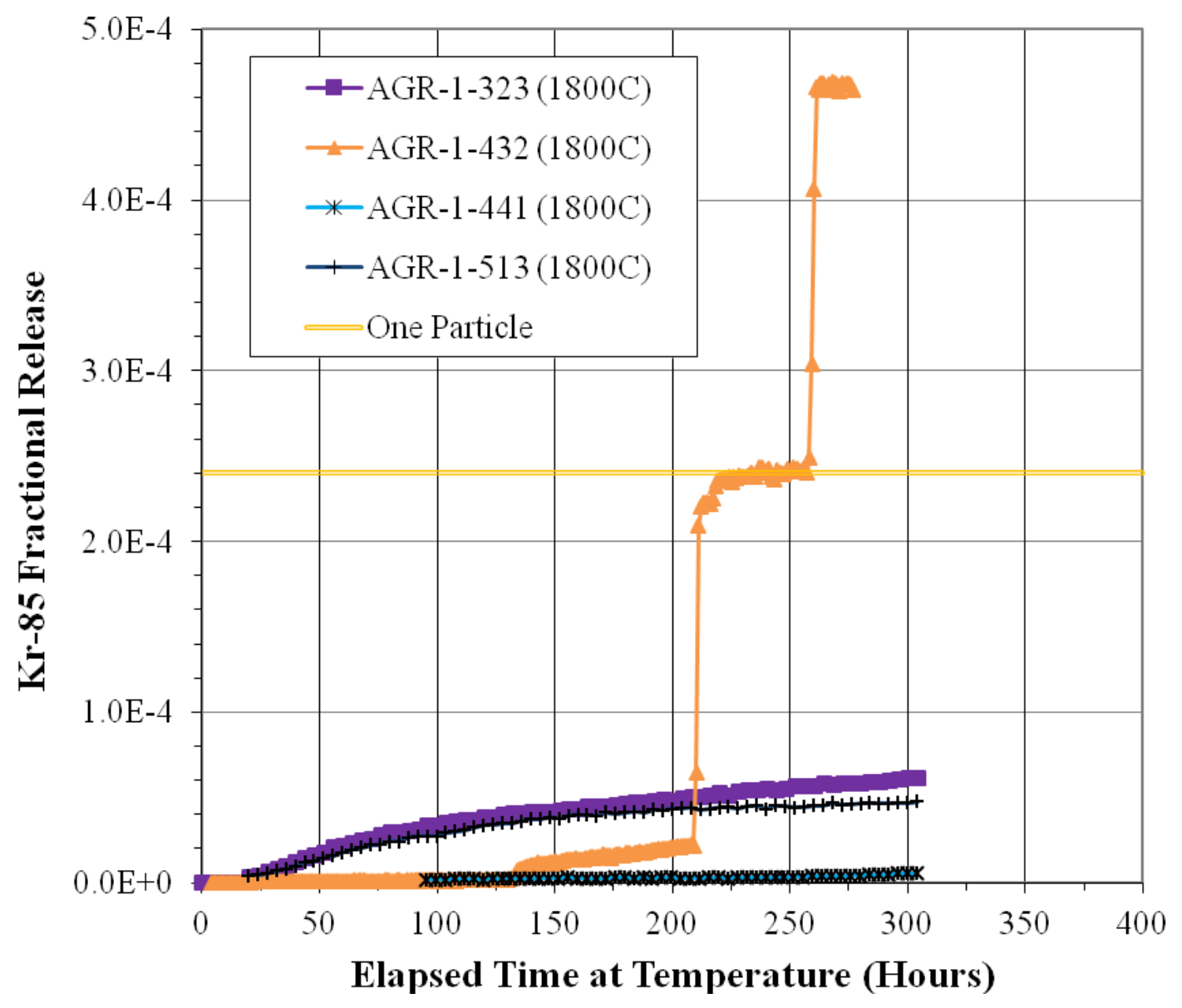

Fig. 15. Krypton release in the $1800{ }^{\circ} \mathrm{C}$ test series. Note that Compact $4-3-2$ was releasing Cs $(\sim 100 \mathrm{~h})$ before its first TRISO failure at $210 \mathrm{~h}$. 


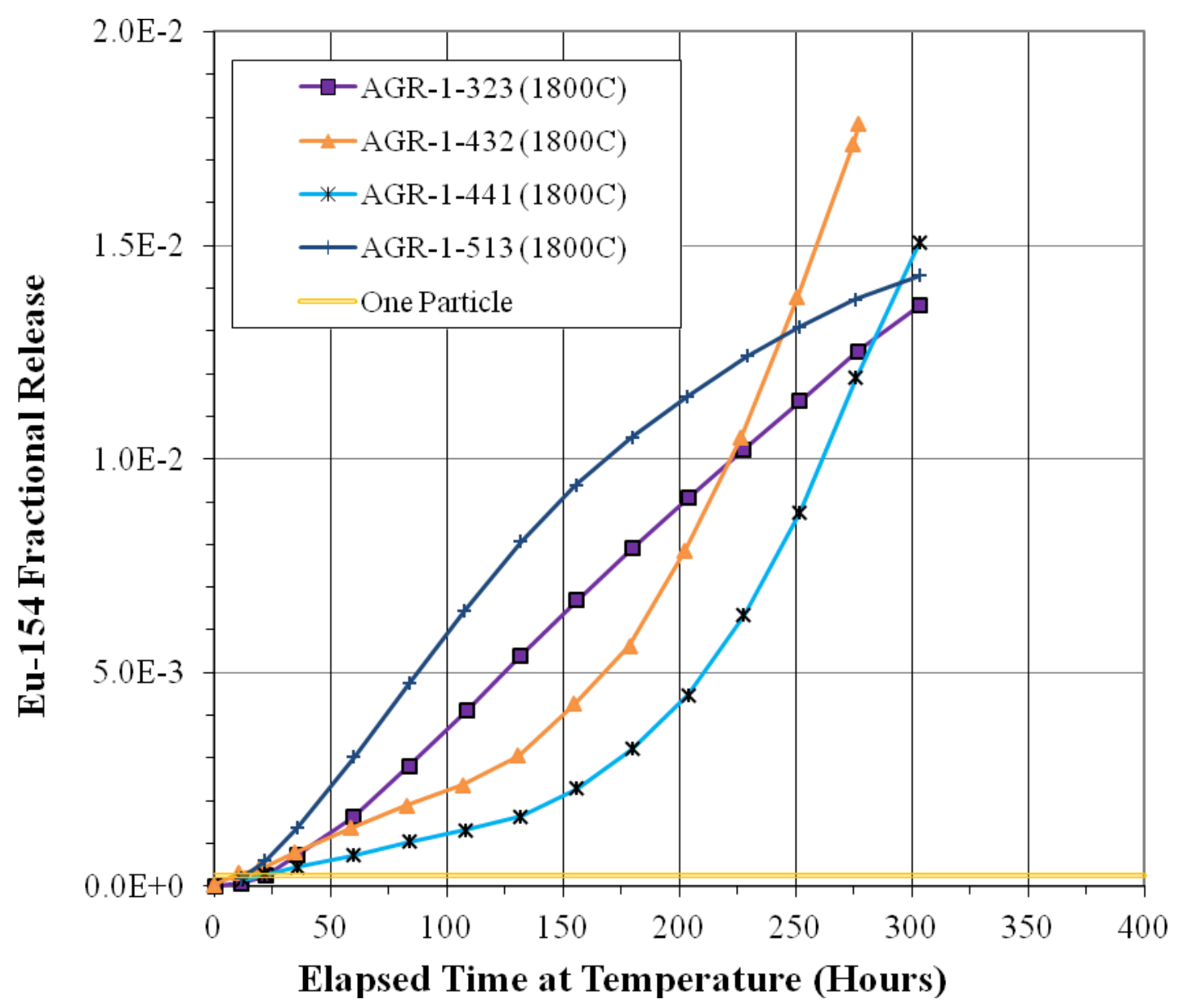

Fig. 16. Europium release for the $1800{ }^{\circ} \mathrm{C}$ series. Variant 3 compacts showed increasing release rate in latter half of test. 


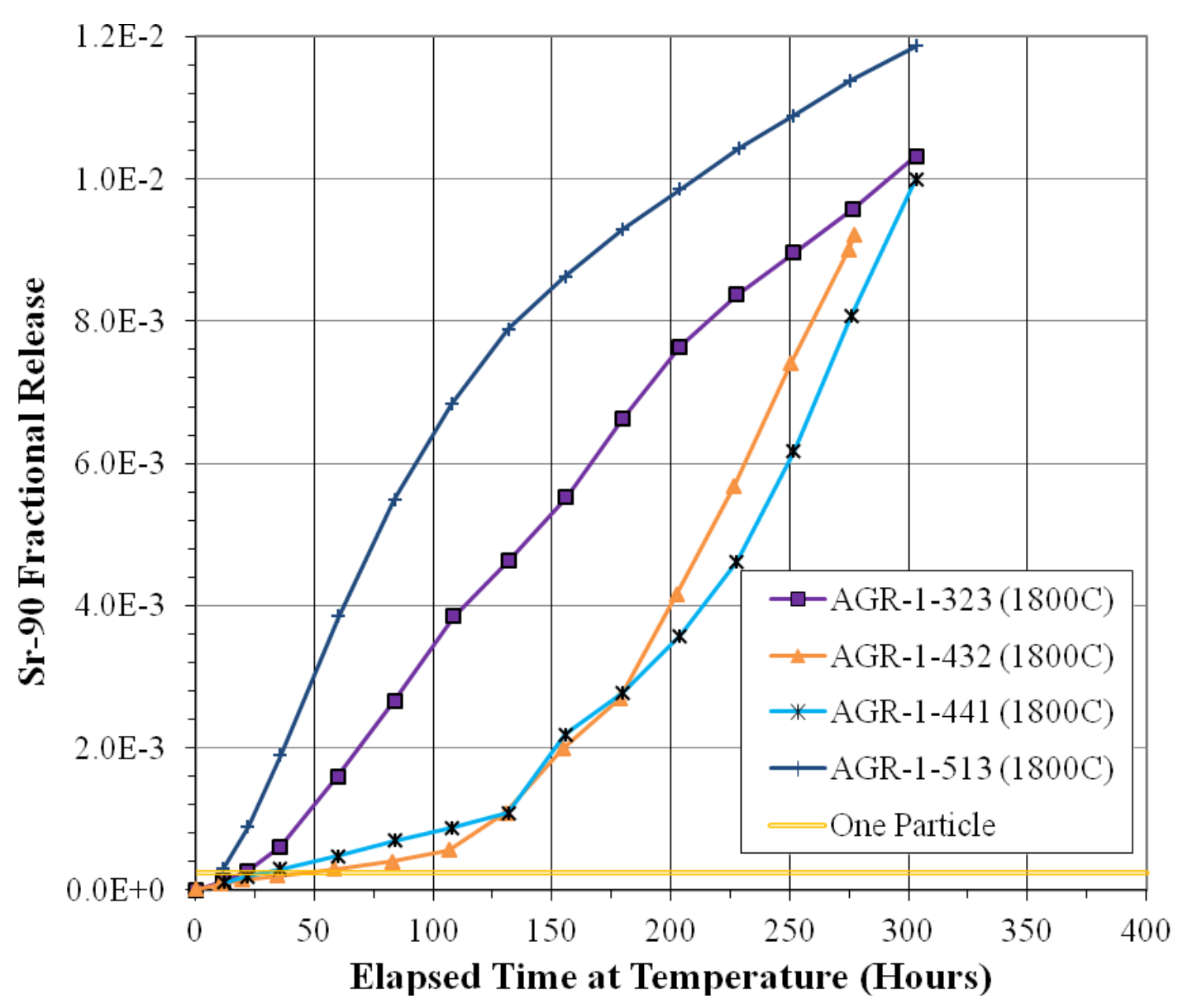

Fig. 17. Strontium release for the $1800{ }^{\circ} \mathrm{C}$ series. Release patterns were similar to europium in Fig. 16.

Interpreting the release patterns in Fig. 16 and Fig. 17 is complicated by the possible variation in the amount of ${ }^{154} \mathrm{Eu}$ and ${ }^{90} \mathrm{Sr}$ released through intact $\mathrm{SiC}$ during irradiation and trapped in the compact matrix and $\mathrm{OPyC}$, as it was available for early release and would be more mobile at this higher temperature. The $1800{ }^{\circ} \mathrm{C}$ heating releases were low enough that depletion of the inventory inside the particles would not be significant, and thus this would not be a reason for the reduction in the release rate from Compacts 3-2-3 and 5-1-3. One possible explanation for the decreasing release rates from Compacts 3-2-3 and 5-1-3 versus the increasing release rates from Compacts 4-3-2 and 4-4-1 would be if Compacts 3-2-3 and 5-1-3 had more Eu and $\mathrm{Sr}$ in the compact matrix and $\mathrm{OPyC}$ and less release through intact $\mathrm{SiC}$, while Compacts 4-3-2 and 4-4-1 had less $\mathrm{Eu}$ and $\mathrm{Sr}$ in the compact matrix and $\mathrm{OPyC}$ and more release through intact $\mathrm{SiC}$. Considerable variation in the europium and strontium inventory outside of intact $\mathrm{SiC}$ has been observed in as-irradiated compacts (Demkowicz et al., 2015-1) and the grain structure of the Variant 3 fuel is different (Phillips et al., 2010); however, further work will be required to determine if these aspects impacted the $1800{ }^{\circ} \mathrm{C}$ release patterns.

Silver release patterns also showed a difference between the Variant 3 compacts and the compacts with coarser-grained SiC (Fig. 18). The increasing release rates in the latter half of the Variant 3 furnace tests implies that diffusive release through intact $\mathrm{SiC}$ may have been occurring at a high enough rate that it was not obscured by contribution from ${ }^{110 \mathrm{~m}} \mathrm{Ag}$ trapped in the $\mathrm{OPyC}$ and matrix at the end of irradiation. This suggests that the coating diffusive behavior at $1800^{\circ} \mathrm{C}$ is significantly higher than at $1600{ }^{\circ} \mathrm{C}$ and that the two $\mathrm{SiC}$ variations may have different behavior at extreme temperatures. 


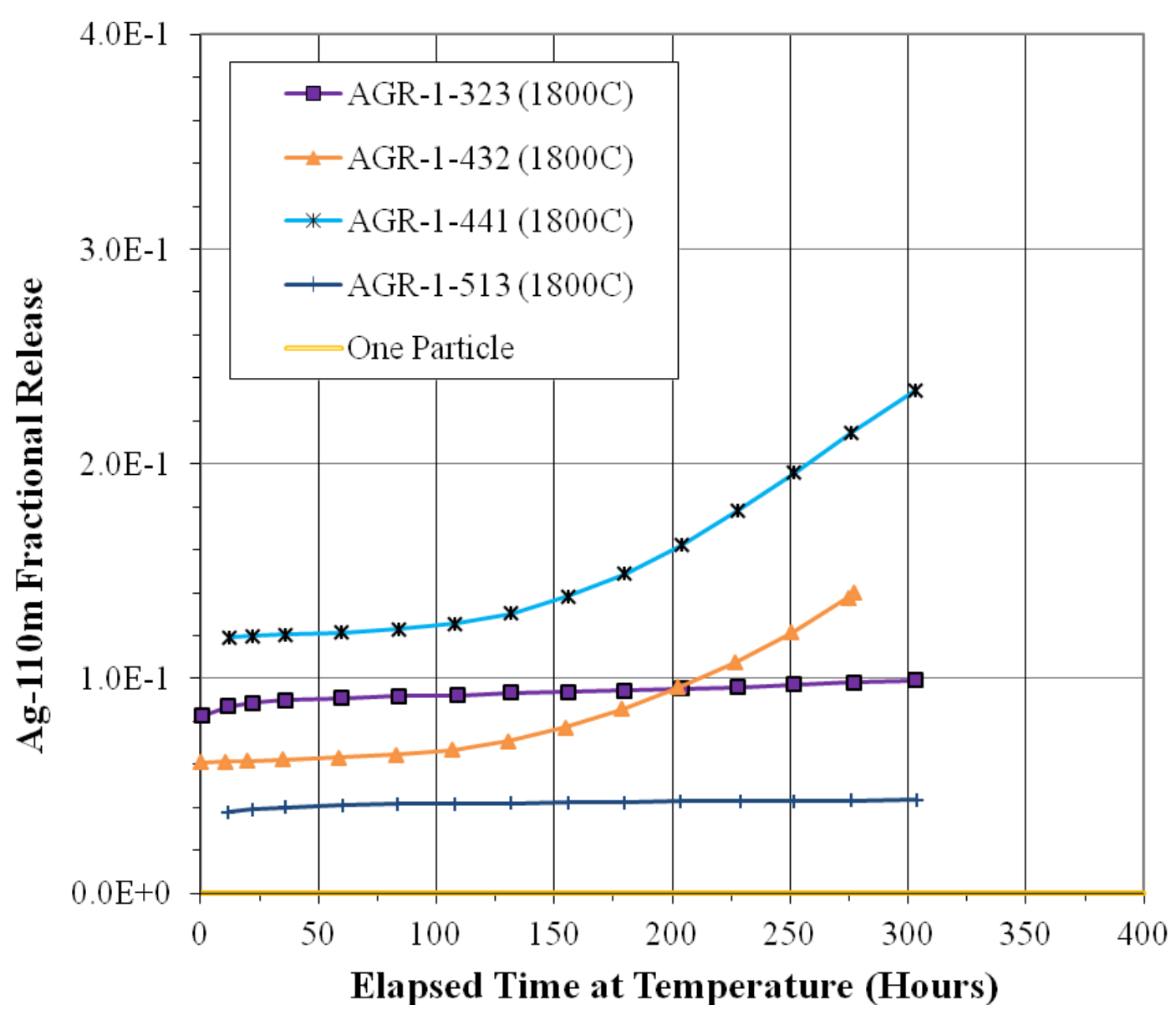

Fig. 18. Silver release for the $1800{ }^{\circ} \mathrm{C}$ series. Like Eu and Sr, Variant 3 compacts showed an increasing Ag release rate in the latter half of the test.

\section{PARTICLES WITH FAILED SIC}

As already discussed, cesium releases at all test temperatures were close to background levels or dominated by individual particles with failed SiC. Locating and examining these particles were an important part of posttest analysis, and details are reported in another paper (Hunn et al., 2015). For compacts tested at ORNL, the IMGA was used to locate particles low in cesium by examining each particle's ${ }^{137} \mathrm{Cs} /{ }^{144} \mathrm{Ce}$ ratio (where ${ }^{137} \mathrm{Cs}$ is released from particles with failed $\mathrm{SiC}$, while ${ }^{144} \mathrm{Ce}$ is mostly retained). Furnace releases were combined with the IMGA analysis of cesium inventory and post-test DLBL to estimate the number of particles that released cesium in each test. However, sometimes particles from $1700^{\circ} \mathrm{C}$ and $1800^{\circ} \mathrm{C}$ testing did not survive the process of electrolytic deconsolidation, acid leaching, and sieving used to separate the particles from the compact matrix prior to IMGA survey, making it difficult to account for all the cesium release and determine the exact number of particles with failed $\mathrm{SiC}$ in these tests. Particles with failed $\mathrm{SiC}$ did not release all of their cesium and what they did release varied, so furnace release results alone were not sufficient for determining the number of particles with failed $\mathrm{SiC}$. Particles with $\mathrm{SiC}$ failures were studied by x-ray imaging and materialographic examination (Hunn et al., 2015). The two particles that released cesium during $1600{ }^{\circ} \mathrm{C}$ testing in the CCCTF were both traced to as-fabricated coating defects, while all the cesium-releasing particles recovered from the 1700 and $1800{ }^{\circ} \mathrm{C} \mathrm{CCCTF}$ tests were found to be cases where irradiation-induced cracks in the IPyC led to palladium build up at the IPyC/SiC interface that eventually corroded through the layer when the particles were held at high temperature during furnace testing. Particles that released cesium in the FACS tests were not subjected to IMGA and post-test microstructural analysis.

\section{SUMMARY}

An extensive series of high-temperature inert-atmosphere testing was undertaken using irradiated compacts from the AGR-1 experiment (Petti et al., 2010). Results from furnace tests on fourteen compacts ( 58,000 particles) were summarized in this paper. Three UCO fuel types with minor coating variations in the IPyC or 
$\mathrm{SiC}$ were tested from $1600-1800{ }^{\circ} \mathrm{C}$. All compacts performed well at these temperatures for testing periods of 300 or more hours.

Krypton release above a small fraction of a single particle's inventory was only detected in one of the compact tests, where essentially $100 \%$ of the inventory was released from two particles at $1800^{\circ} \mathrm{C}$. These particles are presumed to have had failed TRISO coatings that allowed escape of the fission gas, in addition to other radioisotopes.

Cesium retention by intact $\mathrm{SiC}$ was excellent, even up to $1800^{\circ} \mathrm{C}$; cumulative cesium releases in the absence of failed $\mathrm{SiC}$ were less than $5 \times 10^{-6}$ and were often difficult to measure above background contamination. The only significant cesium releases were associated with individual particles with failed $\mathrm{SiC}$ (Hunn et al., 2015). At $1600{ }^{\circ} \mathrm{C}$, data indicates that 3 out of $\sim 33,100$ particles experienced failed $\mathrm{SiC}$ layers during safety testing. At least two of these failures were associated with fracture of the $\mathrm{SiC}$ layer in particles with fabrication defects; the defective $\mathrm{SiC}$ in these two particles remained intact during irradiation, but fractured when heated to $1600^{\circ} \mathrm{C}$. Significant krypton was not released from these particles because the $\mathrm{OPyC}$ remained intact. At $1700{ }^{\circ} \mathrm{C}, \sim 4$ out of $\sim 8300$ particles and at $1800{ }^{\circ} \mathrm{C}, \sim 23$ out of $\sim 16,500$ particles had failed SiC layers; except for the two fabrication defects, all other analyzed particles that showed failures were caused by palladium attack after exposure of the inside of the $\mathrm{SiC}$ layer by irradiation-induced fracture of the IPyC.

A working hypothesis is that europium and strontium release appeared to be dominated by the slow release of these elements from the $\mathrm{OPyC}$ and compact matrix, having been previously released through intact $\mathrm{SiC}$ during irradiation and retained outside of the $\mathrm{SiC}$ by these carbonaceous components. Diffusion through $\mathrm{SiC}$ at the test temperatures cannot be ruled out, but if it is occurring, it appears to be overwhelmed by this other component. This is an area for future work. One exception was that two of the compacts tested at $1800{ }^{\circ} \mathrm{C}$ (both with Variant 3, fine-grained $\mathrm{SiC}$ ) showed indications of increased release rates for europium and strontium that could possibly be linked to their diffusion through the $\mathrm{SiC}$ layer, but further study is required to investigate this possibility.

As might be expected, ${ }^{110 \mathrm{~m}} \mathrm{Ag}$ release was the most prevalent of the radioisotope releases tracked in this study, given that it is known to often exhibit high fractional release during irradiation (Demkowicz et al., 2015-1). In most cases, silver was rapidly released during the ramp up to test temperature and relatively little additional silver was released through the remainder of the test; this can be explained by rapid evaporation of silver residing in the $\mathrm{OPyC}$ and matrix at the beginning of the furnace test, due to previous in-pile release. A secondary release of ${ }^{110 \mathrm{~m}} \mathrm{Ag}$ was observed in the two Variant 3 compacts heated to $1800{ }^{\circ} \mathrm{C}$ (similar to the increased europium and strontium release observed from those compacts); this appears to be most likely related to diffusion of silver through intact $\mathrm{SiC}$. Unusual secondary release of ${ }^{110 \mathrm{~m}} \mathrm{Ag}$ was also observed from a couple of compacts after thermal cycling from elevated temperatures down to room temperature and then back to the test temperature. This effect is currently being studied by additional furnace testing to explore possible mechanisms.

The fission product release behavior observed in this series of heating tests is qualitatively similar to that reported for a heating test performed on loose TRISO-coated UCO particles from the HRB-15B irradiation experiment (Bullock, 1984). Most of the kernel and coating properties were similar to the AGR-1 fuel, with the exception of a lower-density $\mathrm{SiC}$ that was noted to have a laminar microstructure which may have impacted diffusion. After irradiation to $21.7 \%$ FIMA at $860{ }^{\circ} \mathrm{C}$, three sets of ten particles each were heated at 1200,1350 , and $1500{ }^{\circ} \mathrm{C}$ for over $10,000 \mathrm{~h}$ and accumulated release of cesium, europium, cerium, and silver was monitored as a function of time. No cesium release was detected from the UCO fuel particles (two other fuel types included in that study released cesium due to $\mathrm{SiC}$ failure); this result is consistent with the current study where the only significant cesium releases were associated with individual particles with failed $\mathrm{SiC}$.

In the HRB-15B loose particle $1500{ }^{\circ} \mathrm{C}$ heating test, cumulative europium release from UCO fuel reached $37 \%$; the release was noted to be uniform from all particles in the batch and conform to classical diffusion theory. Only at $1800{ }^{\circ} \mathrm{C}$ were there indications of diffusive europium behavior in the current study, while at $1600{ }^{\circ} \mathrm{C}$, contribution from europium in the matrix and $\mathrm{OPyC}$ appeared to dominate the release. Perhaps longer test times would have resulted in measurable diffusion through the SiC in the AGR-1 UCO fuel particles, given the observation of significant diffusion at $1500{ }^{\circ} \mathrm{C}$ over several thousand hours in the HRB-15B particle test. Also in that study, europium release was noted at $1200^{\circ} \mathrm{C}$, with a cumulative release of $6 \%$ after $10,000 \mathrm{~h}$; this is only slightly higher than the typical TAVA compact temperature over the $>14,000 \mathrm{~h}$ AGR-1 irradiation period and could explain how the matrix acquired its europium inventory.

Significant cerium release from the compact was not observed in the AGR-1 heating tests, but post-test DLBL showed a small amount of cerium in the compact matrix $\left(<1 \times 10^{-3}\right)$. This cerium release from the AGR-1 particles included both in-pile and any possible heating test releases, making it difficult to estimate the heating test release separately. Cerium release in the longer HRB-15B loose particle $1500{ }^{\circ} \mathrm{C}$ heating test was $1-2 \%$, and approximately half of that was retained by the thin-walled graphite crucible that held the particles. This relatively lower release and strong retention of cerium by graphite is consistent between both experiments. 
Silver release from the UCO particles in the HRB-15B $1500{ }^{\circ} \mathrm{C}$ heating test was anomalously low and exhibited a very long (>8000 h) breakthrough time; this behavior was conjectured to have been associated with the laminar $\mathrm{SiC}$ microstructure. TRISO-coated $\mathrm{UO}_{2}$ fuel particles included in that study, with higher-density columnar-grained $\mathrm{SiC}$, exhibited shorter but still relatively long breakthrough periods $(>800 \mathrm{~h})$ compared to the duration of the AGR-1 heating tests. This supports the hypothesis that silver release from compacts in the AGR1 heating tests was mostly due to rapid evaporation of silver residing in the OPyC and matrix at the beginning of the test. Like europium, quantitative analysis of diffusive silver release (if any) from AGR-1 compacts would likely require a longer testing period, except possibly in cases that duplicate the secondary silver release observed at $1800{ }^{\circ} \mathrm{C}$ and during temperature cycling.

\section{ACKNOWLEDGMENTS}

This work was supported by the U.S. Department of Energy, Office of Nuclear Energy, under the Very High Temperature Reactor Technology Development Office Advanced Gas Reactor Fuel Development and Qualification Program. Analysis of leach solutions and CCCTF furnace components was provided by the ORNL Nuclear Analytical Chemistry \& Isotopics Laboratory. Analysis of FACS condensation plates and associated leach solutions was provided by the INL Analytical Laboratory. Hot cell activities were supported by the staff of the ORNL Irradiated Fuels Examination Laboratory and INL Hot Fuel Examination Facility.

\section{REFERENCES}

Baldwin, C.A., Hunn, J.D., Morris, R.N., Montgomery, F.C., Silva, C.M., Demkowicz, P.A., 2014. First Elevated-Temperature Performance Testing of Coated Particle Fuel Compacts from the AGR-1 Irradiation Experiment. Nucl. Eng. Design 271, 131-141.

Bullock, R.E., 1984. Fission Product Release During Post-Irradiation Annealing of Several Types of Coated Fuel Particles. J. Nucl. Mater. 125, 304-319.

Demkowicz, P.A., Laug, D.V., Scates, D.M., Reber, E.L., Roybal, L.G., Walter, J.B., Harp, J.M., Morris, R.N., 2012. The Fuel Accident Condition Simulator (FACS) Furnace System for High Temperature Performance Testing of VHTR Fuel. Nucl. Eng. Design 251, 164-172.

Demkowicz, P.A., Hunn, J.D., Ploger, S.A., Morris, R.N., Baldwin, C.A., Harp, J.M., Winston, P.L., Gerczak, T.J., van Rooyen, I.J., Montgomery, F.C., Silva, C.M., 2015-1. Irradiation Performance of AGR-1 HighTemperature Reactor Fuel. Nucl. Eng. Design, http://dx.doi.org/10.1016/j.nucengdes.2015.09.011.

Demkowicz, P.A., Reber, E.L., Scates, D.M., Scott, L., 2015-2. First High Temperature Safety Tests of AGR-1 TRISO Fuel with the Fuel Accident Condition Simulator (FACS) Furnace. J. Nucl. Mater. 464, 320-330.

Hunn, J.D., Jellison, G.E. Jr., Lowden, R.A., 2007. Increase in Pyrolytic Carbon Optical Anisotropy and Density During Processing of Coated Particle Fuel Due to Heat Treatment. J. Nucl. Mater. 374, 445-452.

Hunn, J.D., Baldwin, C.A., Gerczak, T.J., Montgomery, F.C., Morris, R.N., Silva, C.M., Demkowicz, P.A., Harp, J.M., Ploger, S.A., van Rooyen, I.J., Wright, K.E., 2015. Detection and Analysis of Particles with Failed SiC in AGR-1 Fuel Compacts. Nucl. Eng. Design, http://dx.doi.org/10.1016/j.nucengdes.2015.12.011.

Kania, M.J., Nabielek, H., Nickel, H., 2015. Coated Particle Fuels for High-Temperature Reactors. Materials Science Technology 1-183.

Pappano, P.J., Burchell, T.D., Hunn, J.D., Trammell, M.P., 2008. A Novel Approach to Fabricating Fuel Compacts for the Next Generation Nuclear Plant (NGNP). J. Nucl. Mater. 381, 25-38.

Petti, D.A., Maki, J.T., Hunn, J.D., Pappano, P.J., Barnes, C.M., Saurwein, J.J., Nagley, S.G., Kendall, J.M., Hobbins, R.R., 2010. The DOE Advanced Gas Reactor Fuel Development and Qualification Program. JOM 62, 62-66.

Phillips, J.A., Barnes, C.M., Hunn, J.D., 2010. Fabrication and Comparison of Fuels for Advanced Gas Reactor Irradiation Tests. In: Proceedings of HTR2010, Prague, Czech Republic, October, Paper 236. 


\section{BIBLIOGRAPHY}

Baldwin, C.A., Hunn, J.D., Morris, R.N., Montgomery, F.C., Silva, C.M., Demkowicz, P.A., 2014. First Elevated-Temperature Performance Testing of Coated Particle Fuel Compacts from the AGR-1 Irradiation Experiment. Nucl. Eng. Design 271, 131-141.

Bullock, R.E., 1984. Fission Product Release During Post-Irradiation Annealing of Several Types of Coated Fuel Particles. J. Nucl. Mater. 125, 304-319.

Demkowicz, P.A., Laug, D.V., Scates, D.M., Reber, E.L., Roybal, L.G., Walter, J.B., Harp, J.M., Morris, R.N., 2012. The Fuel Accident Condition Simulator (FACS) Furnace System for High Temperature Performance Testing of VHTR Fuel. Nucl. Eng. Design 251, 164-172.

Demkowicz, P.A., Hunn, J.D., Ploger, S.A., Morris, R.N., Baldwin, C.A., Harp, J.M., Winston, P.L., Gerczak, T.J., van Rooyen, I.J., Montgomery, F.C., Silva, C.M., 2015-1. Irradiation Performance of AGR-1 HighTemperature Reactor Fuel. Nucl. Eng. Design, http://dx.doi.org/10.1016/j.nucengdes.2015.09.011.

Demkowicz, P.A., Reber, E.L., Scates, D.M., Scott, L., 2015-2. First High Temperature Safety Tests of AGR-1 TRISO Fuel with the Fuel Accident Condition Simulator (FACS) Furnace. J. Nucl. Mater. 464, 320-330.

Hunn, J.D., Jellison, G.E. Jr., Lowden, R.A., 2007. Increase in Pyrolytic Carbon Optical Anisotropy and Density During Processing of Coated Particle Fuel Due to Heat Treatment. J. Nucl. Mater. 374, 445-452.

Hunn, J.D., Baldwin, C.A., Gerczak, T.J., Montgomery, F.C., Morris, R.N., Silva, C.M., Demkowicz, P.A., Harp, J.M., Ploger, S.A., van Rooyen, I.J., Wright, K.E., 2015. Detection and Analysis of Particles with Failed SiC in AGR-1 Fuel Compacts. Nucl. Eng. Design, http://dx.doi.org/10.1016/j.nucengdes.2015.12.011.

Kania, M.J., Nabielek, H., Nickel, H., 2015. Coated Particle Fuels for High-Temperature Reactors. Materials Science Technology 1-183.

Pappano, P.J., Burchell, T.D., Hunn, J.D., Trammell, M.P., 2008. A Novel Approach to Fabricating Fuel Compacts for the Next Generation Nuclear Plant (NGNP). J. Nucl. Mater. 381, 25-38.

Petti, D.A., Maki, J.T., Hunn, J.D., Pappano, P.J., Barnes, C.M., Saurwein, J.J., Nagley, S.G., Kendall, J.M., Hobbins, R.R., 2010. The DOE Advanced Gas Reactor Fuel Development and Qualification Program. JOM 62, 62-66.

Phillips, J.A., Barnes, C.M., Hunn, J.D., 2010. Fabrication and Comparison of Fuels for Advanced Gas Reactor Irradiation Tests. In: Proceedings of HTR2010, Prague, Czech Republic, October, Paper 236 